\title{
LIVING TOGETHER IN RÍO BEC HOUSES: CORESIDENCE, RANK, AND ALLIANCE
}

\author{
M. Charlotte Arnauld, Dominique Michelet, and Philippe Nondédéo \\ CNRS-Université de Paris Panthéon-Sorbonne, UMR 8096 Archéologie des Amériques, 21 allée de l'Université, F-92023, Nanterre \\ Cedex, France
}

\begin{abstract}
In an attempt to interpret Classic Maya elite and commoner residential patterns beyond usual assumptions about filiation, family cycle, and household economic adaptation, we explore the specific ways people were "living together," in the sense of the coresidence concept, in Maya societies conceived of as ranked societies, or "house societies," as created by Claude Lévi-Strauss. Beyond kinship and economic organization, residential patterns can be understood as part of long-term strategies designed by inhabitants to integrate their social unit into the politico-religious city. The residential system of the Río Bec zone, where a major research project was carried out from 2002 to 2010 , offers a series of well-defined architectural solutions, some of them common to most central lowlands cities, while others are innovative as forerunners of the northern lowlands large multiroom palaces. This paper analyzes Late and Terminal Classic period Río Bec domestic architecture in order to outline the material correlates of coresidence, growth, ranking, and alliance within and between Classic Maya social groupings.
\end{abstract}

One of the most difficult issues raised for Classic Maya society and urbanism bears on the way that social groups of any given entity related to its politico-religious system or, as Fox and colleagues (1996:796; see also Fash 1994:191; Gillespie 2000a:478; McAnany 1995:125; Marcus 2003:86) put it, "how various communities or parts of communities were articulated into larger political wholes." During the 1990s and early 2000s, while debates focused on political systems and their integration capacity (Chase and Chase 1996; Fox et al. 1996; Iannone 2002; Lucero 2003; Marcus 1998; Martin and Grube 2000; Rice 2004), less attention was given to their social basis and components, until more recently when regional projects began investigating intermediate social units situated between the community or polity level and the household level (Canuto and Jaeger 2000; Elson and Covey 2006; Freter 2004; Gonlin 2004; Hutson et al. 2004; Iannone and Connel 2003; Lohse and Valdez 2004; Robin 2003; Schwartz and Falconer 1994). There exists also a renewed interest in the forms of Maya urbanism relative to other early Mesoamerican cities (Arnauld 2008; Arnauld and Michelet 2004; Ciudad Ruiz et al. 2001; Manzanilla and Chapdelaine 2009; Marcus and Sabloff 2008; Mastache et al. 2008; Ponce de Leon et al. 2006; Sanders et al. 2003), within which a structure of neighborhoods (or so-called barrios) is acknowledged by some (see Arnauld et al. 2012; Marcus 2000, 2004; Pyburn 1998; Robin 2003:330-333; Webster et al. 2000). Our specific approach concentrates on domestic architecture, set within a background of settlement pattern data (Nondédéo et al. 2013), in an attempt to explore the coresidence concept and its inferences for highly hierarchical Classic Maya societies and their urban forms. What can we learn from the study of residential facilities under the concept of coresidence that would help to discern social

E-mail correspondence to: charlotte.arnauld@mae.u-paris10.fr integrative modalities? How did ranked individuals live together in close proximity, and what consequences did the sharing of residential space have in the city and the society at large?

"Palace" components, or elite residences embedded in Classic Maya residential groupings are analyzed so as to derive archaeological (material culture) correlates for both coresidence and hierarchy concepts. Such analysis is intended as a contribution to a "palatial archaeology" (Andrews and Fash 1992; Chase and Chase 1992; Christie 2003; Evans and Pillsbury 2004; Inomata and Houston 2000, 2001; see also Eeckhout 2010). In Maya cities, elite residences were mainly large multiroom, vaulted structures that were time-consuming to build and difficult to modify after construction (Abrams 1994). Architectural constraints and solutions can be reasonably generalized across lowland sites, although a degree of variability is patent in many details. In the Río Bec region, on the northern fringe of the central lowlands, a specific style of domestic architecture emerged at sites where innovation seems to have arisen at the shift from the Early to Late Classic period (Taladoire et al. 2013). Generally speaking, if correctly identified and interpreted in a representative house sample, architectural variations, modifications, and innovations are meaningful inasmuch as they can help pinpoint not only structural conceptions and needs, but also even something of the intentional strategies of their builders and inhabitants in their interactions with other components of the settlement at large (Beck 2007; Blanton 1994; Bourdieu 1973, 1977; Cuisenier 1992; Giddens 1984; Hirth 1993; Kent 1990; Kowalski 1987, 1999; Sanders 1990; Terraciano 2001). From such a perspective, recently excavated Río Bec houses offer adequate data considering that they resulted from an initial investment that the local, essentially rural, society had been able to sustain during at least three centuries (Figure 1).

By concentrating on elite residential facilities, the present study aims at clarifying their role in structuring social groups intermediate 


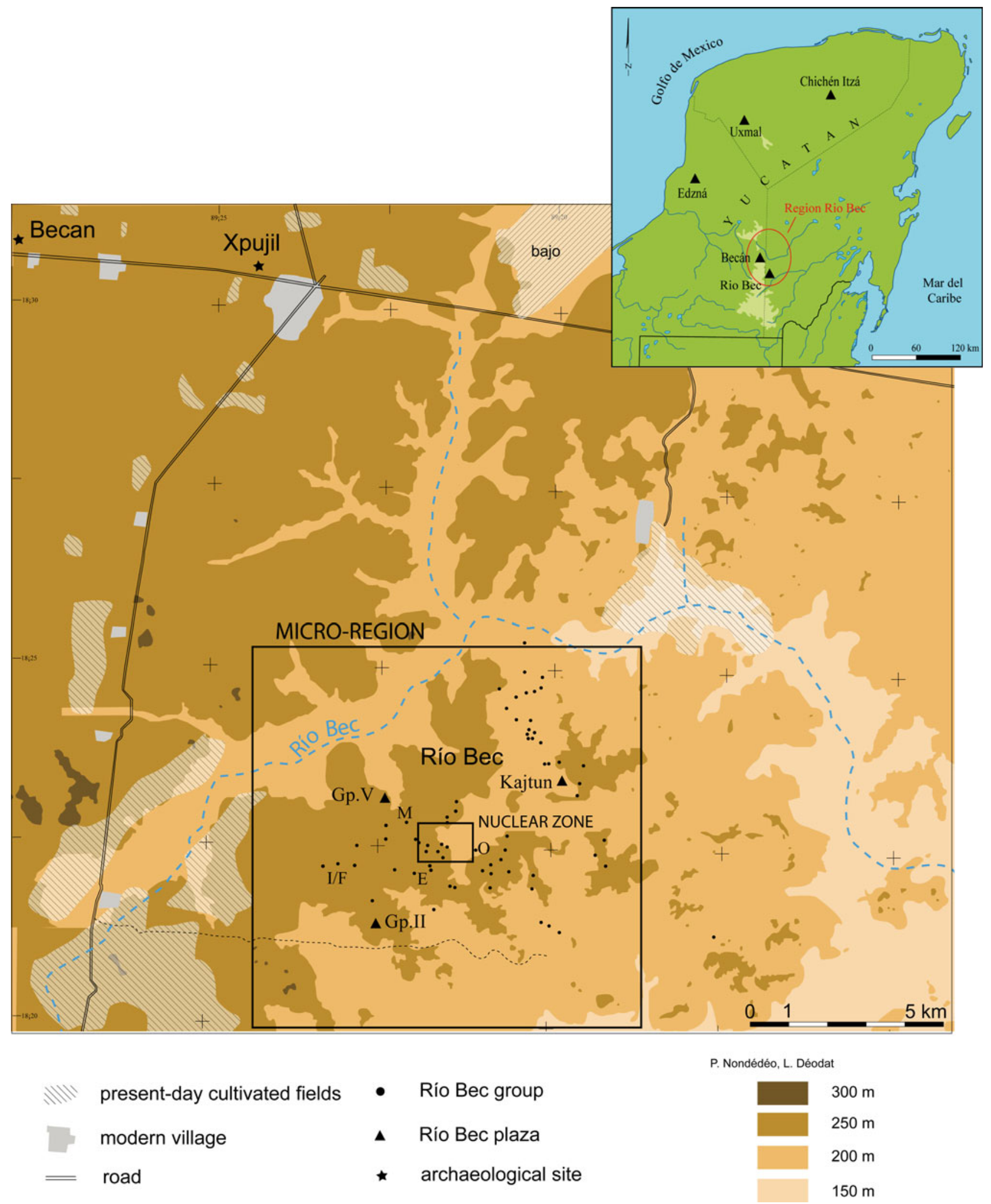

Figure 1. Location of the Río Bec archaeological zone, Campeche, Mexico. Primary research in the region prior to the present project was conducted by Adams (Adams and Jones 1981), Ball (1977; at Becan), Eaton (1975a, 1975b; at Chicanna, located to the southwest of Becan), and Carrasco et al. (1986). The "micro-region" (denoted by the black square) and the "nuclear zone" (denoted by the rectangle) correspond to the differing scales of survey undertaken by the Río Bec Project. Map by Philippe Nondédéo and Laure Déodat. 
between households (as basic units) and the few largest palace complexes to which community institutions were supposedly attached. While Maya elites played off their role in royal courts, they also mobilized and organized local social groupings as large as possible to support their political ambitions. To do so, they invested in building prestigious houses, which were located at the heart of their interactions with dependants, as well as the seat of their social authority. This was possible only at some distance from the king's palace, with a degree of autonomy vis-à-vis the royal court. Our perspective focuses on social groupings and their political role exploring the limits of the kingship-based institutional authority. By virtue of the Mesoamerican coresidence principle, clustered settlements progressively formed around elite houses as localized entities. Empirical data are now accumulating in Classic Maya lowland settlements about the existence of wards, which appear to have been morphologically heterogeneous and are interpreted as internally hierarchical (Fash 1983; Hendon 1991; Kintz 1983; Lemonnier 2009; Sanders 1989; Tourtellot et al. 2003). Coresidence and hierarchy were combined to allow exchange relationships linking commoners to dominant families through several kinds of ties (for example, Sanders' [1989:102] model of the "expanded lineage"), among which marriage was relevant. For the Postclassic period, localized, internally ranked, endogamous units have been documented between the Yucatan Maya and also the Guatemalan Highland Maya (Arnauld 1994, 1996; Hill and Monahagan 1987; Okoshi Harada 2011; Restall 1997). They seem to have been larger than analogous Classic entities and their evolution out of hypothetical Classic antecedents is an open issue. The plausible existence of such social groupings throughout Maya history points to their relevance. Hypothetically, they provide the main framework in which noble/commoner interactions modeled Maya society.

This paper begins by demonstrating that the coresidence and ranking concepts that structured Classic Maya social dynamics may be most fruitfully analyzed through the model of House societies. In this model "...etic and emic constructs may coincide" (Gillespie 2007:26). The social house has obvious advantages as an emic concept, avoiding too rigid ethnocentric categories, yet being a social category extremely common and variable across many societies, it also has pitfalls (Carsten and Hugh-Jones 1995a, 1995b; Henderson and Ostler 2005; Macdonald 1987). Several authors have already dealt with it in relation to kinship studies (Carsten and Hugh-Jones 1995b; Gillespie 2000a, 2007; Hugh-Jones 1993). Watanabe (2004:164) advocated that archaeologists reexamine “... filiations, descent, alliance, and residence [...] to decide which elements in what relation would enable them to make the best sense of what they find in the ground." The challenge is engaging. The Río Bec evidence gives relevance to ranking, coresidence, and alliance, though less to descent, as traced across the residential architecture and patterns we have studied. All were implied in the growth of Maya social groupings. Although generally related to kinship issues, the house society model was primarily defined for hierarchical societies engaged in their historical transition to new political forms (Lévi-Strauss 1982; see also Carsten and Hugh-Jones 1995b; Hugh-Jones 1993:116), sometimes phrased as "chiefdom to State." Its evolutionary content should be endorsed, inasmuch as it appears to fit the Maya lowland historical context during the first millennium A.D. (Sharer and Golden 2004). Because of its historicity, the model also opens a wide spectrum of ethnological and ethnohistorical case studies bearing on integrative modes in hierarchical State, as well as pre-State societies (Beck
2007; Chance 2001; Gillespie and Joyce 2000; Hendon 2007: 292-294; Macdonald 1987; Watanabe 2004).

In those societies, social units were internally ranked and strongly defined and identified by their residential locus as built space, or "the house" (Lévi-Strauss 1982). The importance of coresidence and internal ranking has long been recognized in Classic Maya settlement patterns (Haviland 1988, 1992; Hendon 1991; Tourtellot 1988a 1988b, 1993), but their potential as linked concepts to help unravel the sociopolitical dynamics in Maya cities was only recently recognized owing to the house society model (Gillespie 2000a). On one hand, coresidence is basic to Maya emic conceptions of socioeconomic relationships and territory. On the other hand, when institutionalized at different levels locally (within and between coresidential groups), ranking allowed social units to grow and acquire power mainly through diverse alliance modes. Thus, as an answer to Watanabe's invitation, this is precisely what this paper attempts to demonstrate through the analysis of residential architecture at Río Bec, interpreting data from nine fieldwork seasons (2002-2010) of full-coverage excavation in three monumental groups, together with surveys at distinct scales (Figures 1 and 2).

\section{HOUSE SOCIETIES AND MAYA SOCIETIES}

In modern Western buildings, coresidence entails much more limited social links (Haumont and Morel 2005) than those experienced by the ancient Maya living in Classic period palaces or houses. As members of localized residential groups, neighborhoods or wards, Maya individuals were caught in a web of collective identities and ambitions, and considered themselves related by kinship ties well beyond what biology determines. Maya coresidential groups have sometimes been defined in relation to "households," but demographically, socially, and economically, they tended to be much more as members actively worked toward expansion of their group. This ought to be emphasized since it is widely supported by ethnohistoric, ethnographic, and archaeological (settlement pattern) data on Maya basic communities-members were (and still are) deeply concerned by the growth of their group (McAnany 1993; Ringle and Bey 2001:295; Sanders 1989:98; Tourtellot 1993; Wilk 1990:42). Ambition for growth was more determining factor than concern over issues of descent, which generally favors fission trends, and then hinders growth. Growth in coresidence requires that such trends be controlled, the reason why lineage dynamics, although certainly at play, were limited (Carsten and Hugh-Jones 1995b:14-17; Gillespie 2000a; Ringle and Bey 2001:287-296; Watanabe 2004:160). In the Río Bec case study, growth is mainly expressed in a remarkable way by the construction of many large-scale, multiroom residences from A.D. 600 onward; some of them with extraordinary features like zoomorphic portals, towers with false temples, and roof combs. This growth is primarily what must be economically, socially, and symbolically explained.

Emic, and also etic, coresidential categories help understand the House concept more than kinship does (Gillespie 2000a). Kinship and affinity provide a "language," rhetoric, and an ideology to express the groups' legitimate continuity (Godelier 2004:111; Lévi-Strauss 1982:174). But coresidency has priority, and even partly determines kinship (Annereau-Fulbert 2012). It is a central concept for ethnohistorians and ethnologists who have applied the house model to early colonial or contemporaneous societies of Mesoamerica (Chance 2001; Monaghan 1996; Neurath 2000). 


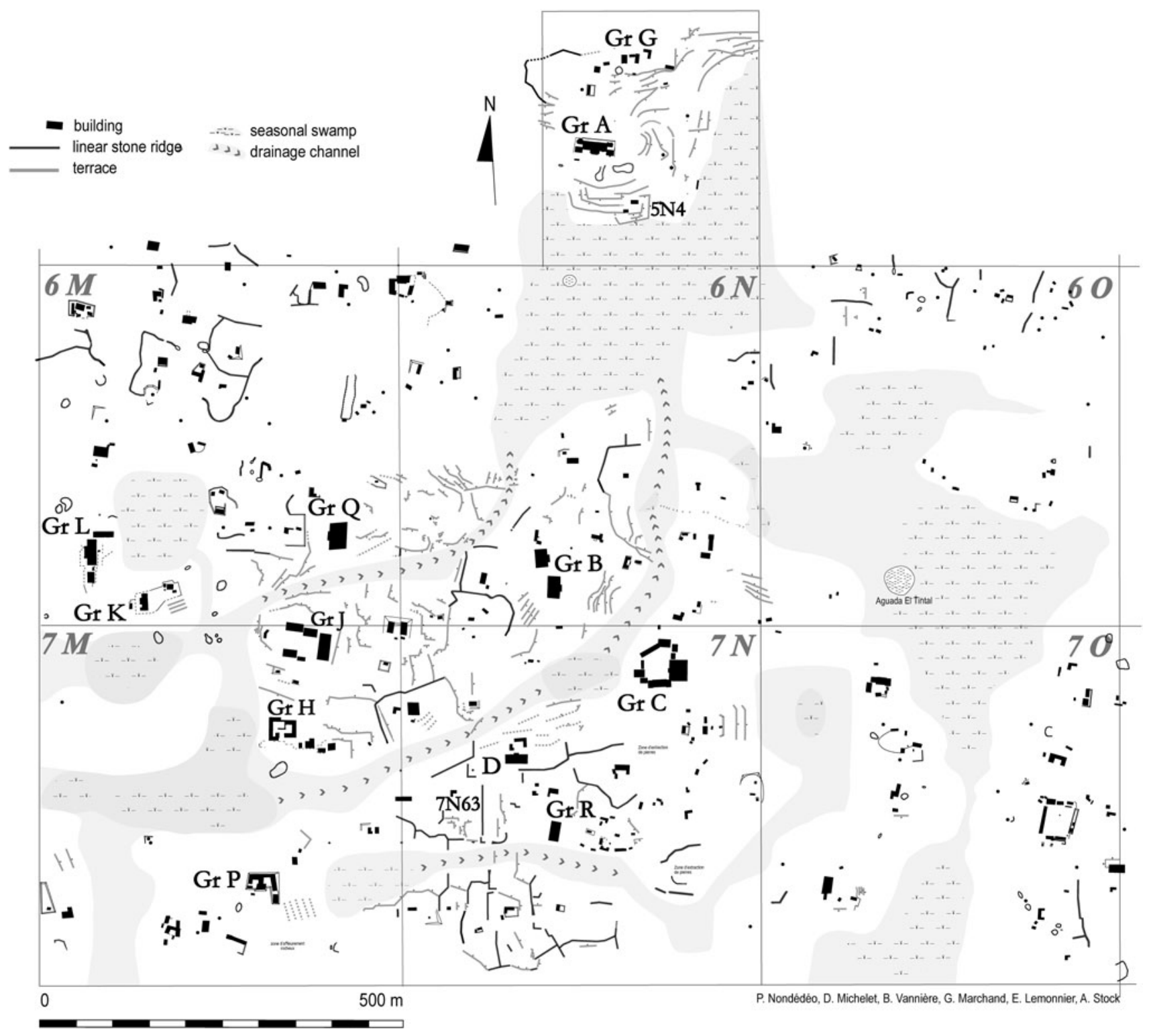

Figure 2. General plan of the Río Bec nuclear zone (159 ha) showing the location of all residential units detected during survey, including the monumental groups labeled with a letter (Groups $E, F, O$ and $M$ are located outside of the nuclear zone; see Figure 1). Entirely excavated units include Groups A, B, D, and neighboring units: Structures 5N4 (Group A), 6N4, 6N5, 6N6, 6N9 (Group B, see Figure 5), and 7N63 (Group D). Ridges and terraces show a higher density in those quadrants associated with Structures 5N, 6N, and $7 \mathrm{~N}$ based on specific surveys conducted by Eva Lemonnier and Boris Vannière. Plan drawn by Philippe Nondédéo, Dominique Michelet, Boris Vannière, Guy Marchand, Eva Lemonnier, and Agnès Stock.

Referring to their corporate, non-kinship aspects, some scholars define the house as "a task-related residential unit" in Mesoamerican agrarian contexts (Neurath 2000; Wilk 1988; see also Farriss [1984:134] regarding the term "milpa gang") or in craft specialization contexts based on shared activities. The task-related definition of a residential unit sometimes corresponds too strictly to the household level (see Hendon 1996; Hirth 1993: 22; MacAnany 1993:80), whereas social houses comprise larger groupings. In a more cross-cultural effort, other ethnologists have made use of the house model to underscore an emic conception of the coresidential unit named "house" in vernacular idioms (Carsten and Hugh-Jones 1995a). As a sort of metaphoric container providing protection and identity to people, the dwelling encompasses pervasive ideas and images easily extended to other levels of social relation, expressing in many languages what a group of people has in mind when wanting to differentiate themselves from others (Henderson and Ostler 2005:153-154; Hendon 1999). Here concerning Classic Maya societies, the core aspect is rather that in a coresidential group: (a) one physical residence was the marker of the social house, and (b) it was inhabited by the group highest ranked members. This particular residence and its occupants ensured the house corporateness in the acceptance of "a moral person" able to transmit wealth (land), names, and titles (material and immaterial properties) to its members, their dependants and offspring (Gillespie 2007:33; Lévi-Strauss 1982:174). This is what makes Maya social organization more amenable to 
those archaeological analyses focusing on settlement patterns and residential architecture.

Although economic cooperation (household, economically corporate groups) and social group composition (kinship, clan, and lineage aspects) are no doubt involved in the house society model, the latter refers primarily to spatial coresidency articulated with social hierarchy. Hirth (1993:31; emphasis ours) observed that, even though the Mesoamerican household is defined by economic cooperation, "the most significant changes in Prehispanic household composition occurred with changes in rank and social control over resources, rather than with the forces governing the means of production." The largest households which appeared between 900-100 B.C. in central Mexico and Oaxaca were elite residences located in politico-religious centers, and Hirth (1993:31) pinpoints the fact that they tended to expand more, that is, to fission less than others groups " $[\ldots]$ because of the prestige which association with the stem household provided its younger members." This corresponds to the core concept of wealth and prestige transmission operated by the house. Elite growth is seen as more directly related to ideological aspects of the emerging ranking system than to economic functional parameters. That the elite households expanded their control of valuable resources is a trivial assertion. What must be understood in societies lacking wage labor (and capital investment mechanisms, see Webster 1992:137) is the way in which elite households achieved control over people able to extract from natural resources culturally defined wealth (material and immaterial). In what kind of reciprocity did they engage? So doing, elite households not only expanded more than others, they also transformed themselves into the core of larger social units as they subordinated other people (Sanders 1989). The house society model has to do not so much with the compositional details of these larger social units, which actually fluctuated much, as with the emergence and development of ranking.

The House concept envisioned in the present study is structurally linked to social ranking and inequality ("as an intrinsic feature," according to Carsten and Hugh-Jones [1995b:10], but see also Beck [2007:4, 7]). As such, it is more specific and narrowly defined than the house category used in a number of ethnological cases of relatively egalitarian, weakly ranked societies. This is important since the house model has been criticized for its universal and indiscriminate applicability (Chase and Chase 2004:144-145; Houston and McAnany 2003; Smith and Schreiber 2005:207). As originally defined by Lévi-Strauss, la société à maison is a crosscultural model applying only to ranked societies and/or societies with incipient stratification (Godelier 2004:107-111; Macdonald 1987:9). In The Way of the Masks, Lévi-Strauss (1982:170-174; Mauzé 1986; see also Gillespie 2000b:26) formulated the concept after quoting what seems to be the final synthesis expounded by Franz Boas concerning the ranked structure of the Kwakiutl social unit he himself called numayma.

"[...] the structure of the numayma is best understood if we disregard the living individuals and rather consider the numayma as consisting of a certain number of positions to each of which belongs a name, a seat or "standing place," that means rank, and privileges. Their number is limited and they form ranked nobility. I am told that among the thirteen tribes of the region extending from Fort Rupert to Nimkish River and Knight Inlet, there are 658 seats [...]. These names and seats are the skeleton of the numayma, and individuals, in the course of their lives, may occupy various positions and with these, take the names belonging to them." (Boas 1966:50).
Boas attempted to reverse his approach from social composition and group morphology ("living individuals") to tangible ranking markers, "names" and "seats." The skeleton metaphor translates the idea of a structure linking living and dead individuals, and consisting of a series of graded status distinctions within and between social groups. This properly differentiates social "ranking" from "stratification," discarding "classes," or "strata" as etic categories (Fried 1967; Peebles and Kus 1977; Sanders 1992; Testart 2005; Webster 1992, 2002). Moreover, as archaeologists coming to grips with settlement patterns at Río Bec, we find Boas' image of a ranking system politically integrating many groups over a large territory quite useful.

Only after this did Lévi-Strauss introduce (as his first case study) the medieval royal houses of European societies. Although the European examples and the Northwest Coast societies (including the Yurok, see Joyce [2000]) had obviously divergent political systems, they shared structurally equivalent ranking systems of numerous graded positions, titles, and names that ordered groups and the individuals within them (Godelier 2004:108-109; Mauclaire 1996:25). In both societies, power positions were obtained on the basis of noble rank well before any State-controlled bureaucracy did so (Helms 1998; Sanders 1989: 103). This signals the fundamentally political function of social houses as institutions, and also grounds the role of physical houses "as locales of political action" (Bowser and Patton 2004: 159; Lévi-Strauss 1979:185, 1982; Lyons 2007:184; Webster and Inomata 2004:160).

Ranking in Maya societies corresponds to a culturally specified "society view" to which many available data are relevant, including ethnological records (Vogt [1983:100] noted that even the modern Maya are extremely "rank-conscious people"), ethnohistoric accounts (Arnauld 1994), iconography (Stone 1989), and epigraphic data (Grube and Martin 1998:138; Houston and Stuart 2001; Martin 2000:177). Glyphic inscriptions also mention highranking marriages (Bricker 2002; Haviland 1977; Josserand and Hopkins 2002; Marcus 1992). As a divine king, the Classic Maya ruler was the paramount individual and apex of the whole status pyramid. Ranking criteria related to either age, generation, birth order or ancestor descent, kinship (consanguine, affine, fictive by adoption...), client/patron links, tribute obligations, political, ritual or military charges, were numerous and complex, so that no individual could have been considered equal to any other.

Radical inequality among individuals and groups must have strongly conditioned agency, especially in marriage strategies. Since all affine families had unequal ranks, endogamous or exogamous alliances were necessarily either hypergamic or hypogamic. Alternating both types, such as a "double alliance," was considered by Lévi-Strauss (1979:184-188, 1982, 1984:216; see also Helms 1998; Watanabe 2004:164) a basic feature of the House institution. A noble person marrying into a higher rank family (hypergamic exogamous alliance) is a matrimonial option often referred to (see, for example, Marcus 1992:223-259), yet another generally overlooked strategy was that a noble family contracted matrimonial alliance with commoner families (Helms 1998:132-138). Double alliance may have been one of the most effective strategies for social groups in their search not only for reproduction, but also growth (Terraciano 2001:173). Like many Mesoamerican coresidential groups, Maya wards were (and still are) also intermarriage groups (see discussion of ward endogamy in Hill and Monaghan [1987:33-42]), a fact which places double alliance at the core of the coresidence/ranking structure. People living in the 
same ward-defined as a socially heterogeneous intermarriage group-maintained real and virtual affine relationships, even when some of the noble offspring were usually engaged into prestigious exogamous alliance. The hypothesis somewhat mitigates essentialist views of a "noble class" and "commoners strata" in Classic Maya cities. By the same token, the Río Bec so-called elite residences were also the dwellings of commoners.

Radical inequality and double alliance would have resulted in individuals of different ranks displaying their differences in age, status, position, while nonetheless obliged to live together and share the same residential space, "under one roof," or as close neighbors at some distance from the great house. The spatial distance dimension was relevant for the individuals themselves (emically), and it also is for archaeologists (etically), having only settlement pattern data to work with (Peterson and Drennan 2005). At what distance from the dominant family house did Maya commoners build their own house in order to obtain something of what the house's "moral person" transmitted to "his/her" members? At Copan, contemporary noble and commoner houses were built almost side-by-side (Hendon 1991), and noble compounds were built close to the royal court (a point discussed by Sanders 1989:103). In Postclassic period highland chinamit groups, as well as in Yucatecan chibal and cuchteel groups, another expression of minimal social (not spatial) distance was the fact that every family chief was entitled to bear the name of the dominant noble family and to cultivate some portion of the corresponding land estate (Hill and Monaghan 1987:33). In accordance with the double alliance principle, he was also authorized to see the palace dwellers as his potential or real affines, which probably entailed some advantages. Through alliance modes, as well as descent rules, the house ensured wealth, name, and title transmission and distribution among the members of a coresidential group in order to warrant its reproduction and growth (McKinnon 2000). Coresidence, ranking, alliance and descent altogether played their role in each place a group had inhabited for some time, growing crops, and building a special house as a landmark. This landmark house could be said to own the land, be noble, and convey this quality to its inhabitants and neighboring dependants. Advantageously for the archaeologist, in the house model, the physical structure is emically the core of the social grouping, more than the "organizational nexus of agricultural production" (McAnany 1993:72).

Coresidency and ranking were not as contradictory obligations as they might appear a priori. Yet, for individuals of differing social ranks willing to display their difference within the same residence or patio group, everyday life may have not been easy. In settlement pattern archaeology, this question again revolves around the distance factor, and in palatial archaeology, it raises many issues to be dealt with through a careful study of morphological details. Río Bec residential facilities have much to tell us when the data are submitted to this specific line of questioning.

\section{RÍO BEC RESIDENCES}

Classic Maya lowland "palaces" are narrow vaulted range structures, with rooms arranged linearly following the long axis, often in double rows "in tandem" (one front, one rear). At Río Bec, some structures have a dozen rooms or more (Figure 3). The tripartite ground plan (Christie 2003) is well represented, either in a simple form with three to five rooms in one row, or a complex form with tandem and transverse rooms (Harrison 2003). Superficially, complex tripartite buildings look like quadrangle palaces common

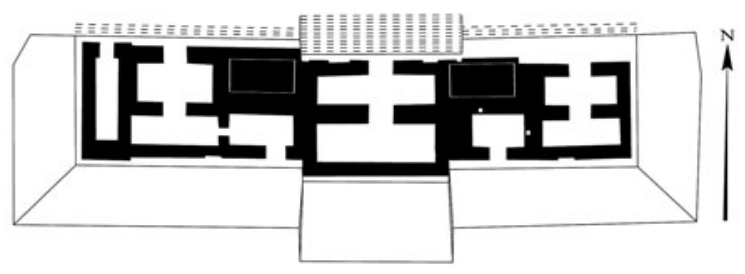

(a)

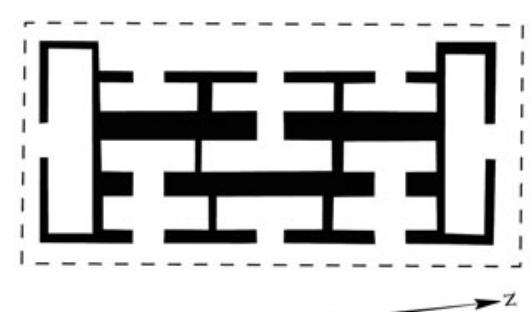

(b)

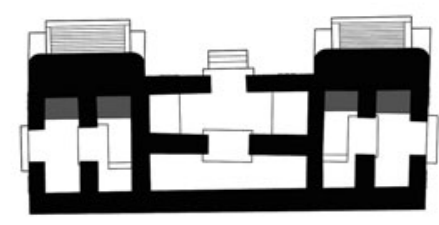

$z<+(c)$

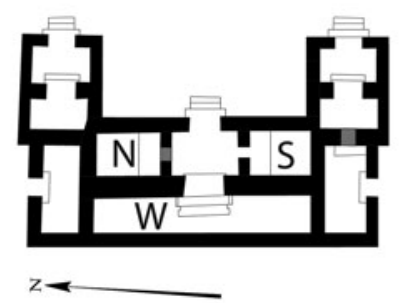

(d)

$0 \quad 5 \quad 10 \mathrm{~m}$

$\mathrm{Ph}$. Nondédéo

G. Marchand

M.Ch. Arnauld

Figure 3. Examples of tripartite residences in Río Bec: (a) Ceibarico Structure 1, (b) Group O Structure 1, (c) Group B Structure 6N1, (d) Group B Structure 6N2, with central rooms coded N (north) and S (south). Lateral rooms in (b) and central ones in (c) and (d) are more than $10 \mathrm{~m}$ in length and qualify as meeting halls. Plan and drawings by Philippe Nondédéo, Guy Marchand, and M. Charlotte Arnauld.

at central lowland sites, but they were more difficult to buildbecause of vault transversal connections-and they conspicuously display their main façade while closed quadrangles rather hide façades (see Michelet et al. [2013] for a detailed description of Edifice A). Each room has an entrance door centered in its façade, and most of them have an inner masonry bench fronting the door. Aside from the bench, which was used as a seat and bed, the best evidence for a residential function of all structures under study is the existence of associated kitchens located in separate unvaulted structures (Déodat and Arnauld 2012). Other diagnostic features are exterior secondary middens, interior niches set in walls, cord-holders framing doorways for curtains to afford privacy, engraved graffiti on walls, and beam holes in vaults for storage space. Patio floors and stairway steps appear normally worn indicating that occupation had been continuous rather than 
temporary or intermittent. Excavated middens all date to the Late-to-Terminal Classic and are not abundant due to the recycling of earlier middens into architectural fills. While this gives an idea of the continuity in building activity (Arnauld 2011), it leaves only shallow deposits and little chance to find evidence for craft activities and portable artifacts (Andrieu 2013; Carballo 2009; Smith 1987). Floors were carefully swept clean, except for ash heaps left by termination rituals. The evidence for social differentiation comes mainly from the size and elaboration of houses.

Doorways, benches, and partition walls were built in such a way that modification to adapt the house to family growth required heavy masonry work, mainly because of complications caused by the vaulted roofs (Postclassic period residences certainly brought some progress). Access stairways are important components of many residences since differences in outer- and inner-floor levels are marked. Quality of veneer cut-stone masonry is excellent, and more diversified on long Río Bec façades than on most central lowland buildings, in some cases with stone-mosaic motifs in panels framing doors - even with roof combs - a feature typically restricted to temples in the central lowlands. In one of the Group B largest residences, coded Structure 6N2, we discovered benchfront painted stones with bright colors including glyphic inscriptions (Arnauld and Lacadena 2004) (see Figures 12 and 13).

Part of a Maya lowland tradition, but differently interpreted by innovative Río Bec builders, these features make up an architectural and dwelling system in terms of: (a) a technical building process (Gillot 2011), (b) a post-building modifying process required by the (ideally) increasing number of occupants, and (c) a number of specific claims, practices and behaviors of coresidents constrained by social requirements. Table 1 describes the system, characterized first by stone architecture with strong basement and foundation walls reflecting continuity and stability of the House; second, by a nested arrangement of clustered rooms and houses allowing growth; third, by inner social ranking expressed by a tripartite layout of cells (in the largest houses), distinct floor levels and cell sizes; fourth, by a definite capacity of attraction into storage rooms and meeting halls; fifth, by social identity and corporateness claimed by highly visible roof and façade composition making up a "reception scenery" (Arnauld 2007; Arnauld and Michelet 2010); and, sixth, by furthering the nested arrangement and claiming social status, with inner benches visible through the entrance doors. Some of the benches were decorated and framed by the façade producing some sort of integrated artwork, which we consider to have functioned as scenery for reception of visitors. The present study focuses upon architecture and as such it is part of an "archaeology of Maya palaces" as much as it is an "anthropology of the house" (Carsten and Hugh-Jones 1995b).

All Classic Río Bec physical houses were not social houses (see Gillespie 2007:29). As much as the building per se, the useful analytical unit is the dwelling unit (house cluster) (Hutson et al. 2004:79-81) defined by one shared kitchen, rather than shrines or ritual structures which are almost nonexistent at Río Bec, a point we will revisit further on. We entirely excavated nine such units, that is, clearing all rooms and interior floors of their 23 structures (in total), even stripping much of their exterior floors in Groups A, B and D (Table 2). On the basis of spatial distance, visible boundaries, and temporal construction sequences, five units are included in one (emic) social grouping corresponding to Group B, two similarly make up Group A, while Group D was only one unit with Structure 7N63 as a distinct neighbor unit. As developed elsewhere (see Nondédéo et al. 2013; Taladoire et al. 2013), Groups A, B, and D are located in the most intensively surveyed area, the project "nuclear zone" (159 ha) (see Figure 2).

Table 1. Parameters of the Río Bec architectural and dwelling system

\begin{tabular}{|c|c|c|}
\hline ARCHITECTURAL PARAMETERS & MAIN DESCRIPTIVE FEATURES & SOCIAL CORRELATES \\
\hline 1. Media & Specialized cut stone (vault, lintels..), lime mortar & DURABILITY \\
\hline Basal platform & Strong fill with retaining walls & CONTINUITY \\
\hline Foundations & Foundation walls, earlier structures, axial burials & STABILITY \\
\hline 2. Group composition and layout & $\begin{array}{l}\text { Nested arrangement of houses and rooms: } \\
\text { "dominant house", lesser houses, separate kitchen; } \\
\text { in pair, in line, open patio, enclosed patio }\end{array}$ & $\begin{array}{l}\text { FLEXIBILITY } \\
\text { RANKING } \\
\text { (generation) }\end{array}$ \\
\hline Planning modification and expansion & $\begin{array}{l}\text { Foundation ready for walls to be built, } \\
\text { inset panels as false doors to be opened }\end{array}$ & $\begin{array}{l}\text { GROWTH } \\
\text { GROWTH }\end{array}$ \\
\hline 3. Ground plan & Differentiated rooms in one building: & \\
\hline Horizontal division into rooms & Tripartite plan: core and lateral wings, tandem & FILIATION \\
\hline Vertical floor levels & Stairways and raised floors & RANKING (birth \\
\hline Distinct room sizes & Long halls, medium-sized rooms, small cells & order, status) \\
\hline Entrance doors to rooms & Axial, on front, and lateral façades & PRIVACY \\
\hline 4. Inner volumes & Storage rooms and meeting halls & $\begin{array}{l}\text { ATTRACTION OF } \\
\text { WEALTH AND } \\
\text { PEOPLE }\end{array}$ \\
\hline 5. Façade composition & $\begin{array}{l}\text { Vertical panels and horizontal moldings, } \\
\text { zoomorphic entranceways, double towers }\end{array}$ & $\begin{array}{l}\text { IDENTITY and } \\
\text { ONTOLOGY }\end{array}$ \\
\hline Roof & roof combs, false temples, masks & of \\
\hline Decorative elaboration & $\begin{array}{l}\text { Earth monster (zoomorphic, rarely } \\
\text { anthropomophic) } \\
\text { axial reception scenery }\end{array}$ & $\begin{array}{l}\text { MORAL PERSON } \\
\text { conferring nobility }\end{array}$ \\
\hline 6. Inner benches & $\begin{array}{l}\text { One bench per room axially visible from outer } \\
\text { space. Variation in presence/absence of lower } \\
\text { niche and decoration/inscription (painted or sculptured) }\end{array}$ & $\begin{array}{l}\text { PRESTIGE } \\
\text { STATUS } \\
\text { TITLES }\end{array}$ \\
\hline
\end{tabular}


Table 2. The nine dwelling units excavated (complete exposure) from 2003-2009 in the Río Bec nuclear zone ( $\mathrm{n}=23$ ). Each unit is labeled following the code of its dominant house.

$\mathrm{X}=$ presence. "Halls" are rooms greater than $10 \mathrm{~m}$ in length, probably used as venue for meeting. Structure typology and assigned ranks are described by Nondédéo et al. [2013:Tables 8 and 9]. Only units occupied during the Late-to-Terminal Classic period were rank ordered, an analysis performed after excavations were complete (no units of Rank II and IV were completely excavated).

\begin{tabular}{|c|c|c|c|c|c|c|c|c|c|}
\hline Group UNIT/Structure PU : per unit & B $6 \mathrm{~N} 1$ & A $5 \mathrm{~N} 2$ & D 7N1 & B 6N6 & B $6 \mathrm{~N} 4$ & A $5 \mathrm{~N} 4$ & / 7N63 & B 6N9 & B $6 \mathrm{~N} 5$ \\
\hline Total of structures PU & 5 & 2 & 5 & 2 & 3 & 2 & 1 & 2 & 1 \\
\hline Type of dominant house & $\mathrm{M} 9+\mathrm{M} 8$ & M9 & M8 & M7 & M6 & M7 & M6 & M6 & M5 \\
\hline Platform height of dominant house & $2.5 \mathrm{~m}$ & $1.5 \mathrm{~m}$ & $2 \mathrm{~m}$ & $2 \mathrm{~m}$ & $1.5 \mathrm{~m}$ & $1 \mathrm{~m}$ & & & \\
\hline Total of rooms PU & 19 & 15 & 6 & 5 & 3 & 3 & 2 & 2 & 1 \\
\hline Total of tandem apartments PU & 6 & 5 & 1 & & & 1 & & & \\
\hline Total of tripartite divisions PU & 3 & 5 & & 1 & & & & & \\
\hline Basal moldings & $\mathrm{X}$ & $\mathrm{X}$ & $\mathrm{X}$ & $\mathrm{X}$ & $\mathrm{X}$ & & & & \\
\hline Inset panels on façade & $\mathrm{X}$ & $\mathrm{X}$ & $\mathrm{X}$ & & & & & & \\
\hline Decorated panels & $\mathrm{X}$ & $X$ & $\mathrm{X}$ & & & & & & \\
\hline Hall count per unit & 4 & 4 & 2 & & & & & & \\
\hline Towers (and Structure 5N2 temple) & 2 & 3 & & & & & & & \\
\hline Roof comb or mask & $\mathrm{X}$ & & & & & & & & \\
\hline Carved cornice & & $\mathrm{X}$ & & & & & & & \\
\hline Human figures in decoration & $X$ & & & & & & & & \\
\hline Assigned Rank & $\mathbf{I}$ & I & III & $\mathbf{V}$ & $\mathbf{V}$ & $\mathbf{V}$ & $\mathbf{V}$ & Early & Late \\
\hline
\end{tabular}

The 23 excavated structures (Table 2) are part of a database of 501 structures (excluding terraces and other agrarian features). These structures have been ranked into four vaulted house types (M9 to M6), two unvaulted types (M5, M3), one platform type (M4), a few special structure types, and two types of rubble piles accounting for $30 \%$ of the corpus (Nondédéo et al. 2013:Table 6). Each excavated unit has one dominant house; for example, Structure $6 \mathrm{~N} 1$ (the famous Edifice B) is the dominant residence of Unit 6 N1. The latter is itself the dominant unit in Group B.

In effect, all contemporary units have also been rank ordered, that is, 90 units occupied in Late-to-Terminal Classic times, defining Ranks I (the highest) to VI (Nondédéo et al. 2013:Table 9). The criteria used in this rank ordering are summarized in Table 2. They combine the parameters shown in Table 1 with others that archaeologists have used in rank ordering residential compounds (Abrams 1994:76-95; Adams and Jones 1981; Carmean 1991; Kurjack 1974; Willey and Leventhal 1979; see also Sanders 1989:98). In social terms, Rank I units like Structures B-6N1 or A-5N2 reflect households able to have formed and maintained relatively large social groupings within and around their core house. Rank III units may represent old declining houses, or houses in the process of growth. Smaller units were being attracted by, and absorbed into, their neighboring large residence, or they resisted and maintained their own existence (Arnauld 2011). Synthesizing architectural, demographic, and agrarian evidence would probably allow us to determine on the ground composition of the largest Río Bec social houses by A.D. 850. We turn here to forward some hypotheses about the formation of supra-household groupings in the case of Río Bec Groups A, B and D, as well as possible alliances between them and neighboring groups (see also Lemonnier and Vannière 2013; Nondédéo et al. 2013).

\section{STONE ARCHITECTURE AND FOUNDATIONS: HOUSE CONTINUITY}

That houses built of stone will stand longer than houses made of perishable material is a truism. Given the very soft limestone available at Río Bec, however, it is not a certainty that it will resist climate-induced weathering better than hard wood, at least on a three-to-four generation time scale. It is possible that Preclassic period prestigious buildings were built of precious wood on high masonry basements. But from the Early Classic period onward, cut stone was preferred, allowing veneer and sculptured façades thinly coated with bright-colored stucco, and saving time since limestone is easier to work than hard wood. Late Classic platforms are lower than their Late Preclassic and Early Classic counterparts, but at Río Bec the Terminal Classic saw a renewed vogue of high platforms for large-scale residences (6 to $8 \mathrm{~m}$ ). Cut-stone buildings erected on masonry platforms were strong symbols of social group stability and continuity (Beck 2007). In tropical conditions, the good preservation of Río Bec buildings after 10-12 centuries of abandonment is mainly due to the quality of their platform fills, lime mortar, and retaining walls. Generally speaking, the building technique is the same at Río Bec as in the central lowlands; that is, beginning with a thick wall to contain the basement fill and form the rear side of the superstructure, then erecting the parallel central and front walls (for tandem rows), all three deeply founded on bedrock to support the main vaults, and finally spreading the upper layers of fill to prepare the inner floor surfaces. Stucco floors, benches, and front stairways were the final added elements. Non-intrusive burials are sometimes found under the rear wall or close to it at the base of the fill in the structure axis under the central room bench (for example, at La Joyanca; see Arnauld et al. 2004:91), but at Río Bec in all known cases they were placed within an earlier structure, a specific location that allows us to interpret them rather as termination/foundation deposits (Pereira 2013). Axial burials appear to have been made only when a new house was built on an earlier house, its short axis matching exactly the axis of the earlier house (Pereira 2013). The significance of this specific geometry expressing house continuity in the place where ancestors had lived cannot be overemphasized (Beck 2007:7-8; Gillespie 2000c, 2001; Hendon 2000:49; McAnany 1998:279; Michelet et al. 2010; Webster 2002:145). 
In contrast, when houses had to be rebuilt at some distance from the old one, ceramic deposits in platform fill may have also symbolized continuity in dwelling. In Groups A, B, and D, several test-pits into structural fill produced quantities of sherds (and chert), sometimes clustered as if they had been thrown out of baskets brought from some abandoned dwelling (we term these features "basketloads") (see Stanton et al. 2008:239). Such ceramic lots are readily noticed on typological distribution tables as earlier coherent ceramic components. Axial burials and ceramic concentrations can be interpreted as closing a time period and opening a new one, reinforcing the sense of social continuity from earlier to later residences.

\section{COURTYARDS, DOORS AND APARTMENTS: HOUSE GROWTH}

In Classic Maya palaces, courtyards, doors, and internal partition walls are usually understood as means to control circulation, a function they certainly had (Liendo Stuardo 2003). But they also connect distinct built spaces, separated to avoid promiscuity and to permit expansion of dwelling quarters when family growth required additional space (Kurjack 2003:282-287; see also Hillier and Hanson 1984). Constraints of vault construction rendered the addition of rooms a complex matter. Growth did not mean just new people to be sheltered, but also quality of added dwelling spaces as compared to the existing ones. Higher-rank individuals entering the house probably demanded better conditions of privacy and prestige. Flexibility of the dwelling system was required so as to respond to such demand.

In the central lowlands, courtyards enclosed on four sides or quadrangles with limited points of entry are thought to be late outcomes (often from the Terminal Classic period) of long-lasting achievements. While they may have ensured social segregation, and even defense in some cases, quadrangles generally resulted from long building sequences, since adding one structure after the other on each of the patio's four sides was a logical option for growth (Breuil-Martinez et al. 2004:80; Haviland 1988; Tourtellot 1988b). Among the Río Bec 72 monumental groups, however, closed quadrangles are scarce and even in the nuclear zone where smaller patio groups were recorded, structures on all four sides are uncommon (Figures 2-6) (see Nondédéo et al. 2013:Tables 2 and 7). To build one's house outside of an already existing cluster was a frequently undertaken option, and this splitting process prevented the development of patio forms. There is in Río Bec nothing approaching the complex system of large patios lined with small
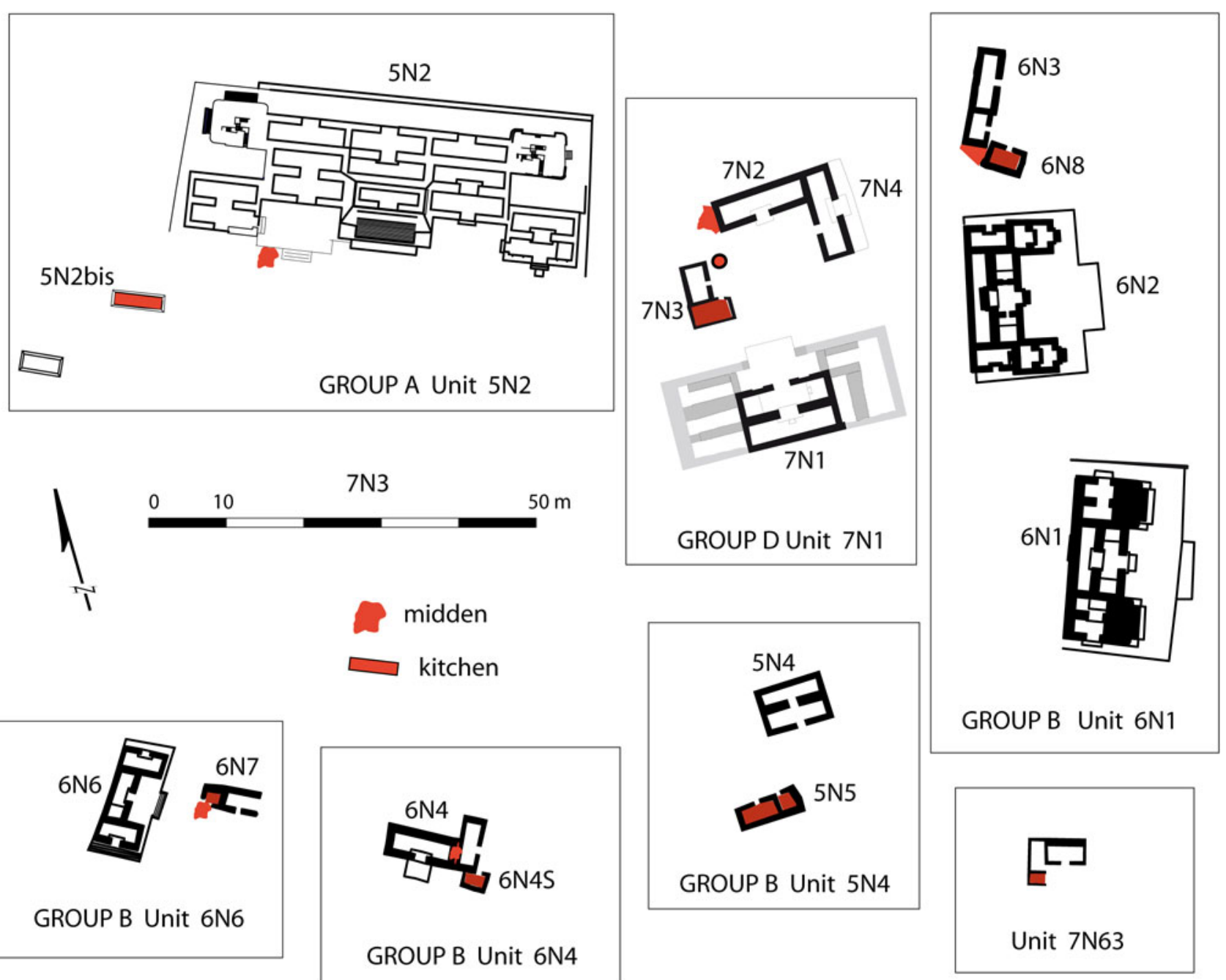

GROUP B Unit 6N4

Figure 4. Seven of the nine excavated dwelling units at Río Bec. Adapted from Déodat and Arnauld [2012:Figure 2]; drawing by Laure Déodat. 


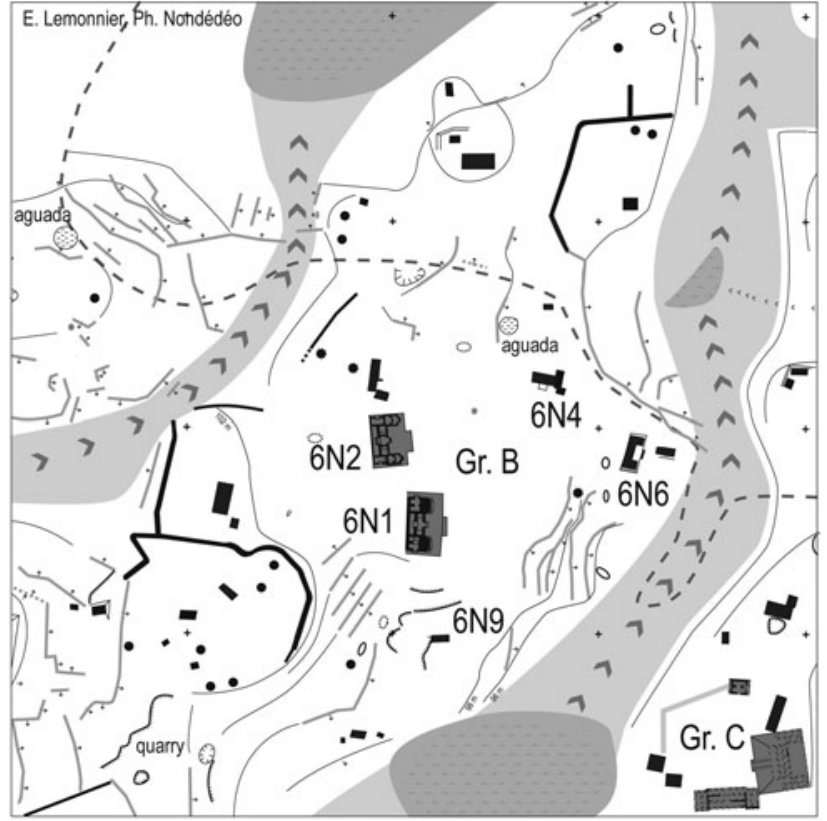

Figure 5. Río Bec Group B and neighboring units. Linear stone ridges are in black, terraces in grey, and drainage channels in grey with arrows. Drawing by Eva Lemonnier and Philippe Nondédéo.

adjoining structures known from Copan neighborhoods (Hendon 1991, 2012; Webster 2002:20-21), or the extraordinary room agglutination of late palaces in northern Yucatan (Kowalski 2003: 222, 224, 227). Living quarters were expanded by building a second tripartite house perpendicular to the earlier one (for example, Group L), or on its rear side (Structure A-5N2; see
Figure 7), or in line with it (Structures B-6N1 and B-6N2, built roughly at the same time). Even during the Terminal Classic period, when they are most numerous in the lowlands, four-sided patio groups were not favored at Río Bec, probably in part to avoid "frontal visibility of other opposing structures" typical of the quadrangle layout (Schwarz 2009:421; see also Gonlin 2004: 244). Confirming the concern for privacy, Structures $6 \mathrm{~N} 1$ and $6 \mathrm{~N} 2$ are open on three faces (Figure 4), and north-south aligned but with a small gradient so that the main-façade doors of Structure $6 \mathrm{~N} 1$ are not visible from Structure 6N2. In Group D (Figure 6), one of the few patio units, Structure 7N4 was open on its rear façade outside of the patio in the first stage, then later on the door was sealed up and a new one was opened on the front façade, under the visual control of patio coresidents. Another concern seems to have been that long façades were left visible, rather than shielded by neighboring houses in patio groups. Privacy was defined in terms of internal social relationships within the group, yet some degree of external visibility was needed. Río Bec was a rural settlement with no proximate public plazas, and it is probable that no local rulers were in a position to control domestic sumptuary display by their subordinates. Denser settlement in cities like Calakmul or Becan offered conditions to which closely knit residential quadrangles probably better suited needs in terms of both privacy and subordination (Martin 2000: 175-176). At Río Bec, however, social groups felt free to build residences as visible claims of rank and status.

In Maya palaces, doorways determine the number of dwelling quarters in one large-scale house: each room had only one access door and most probably lodged one nuclear family, or one spouse with children-polygyny does not alter the pattern. The tandem layout consists of one inner room paired with one outer room, both with axial doors, and the inner room properly providing the private family space (as observed by Hernan Cortés, cited in
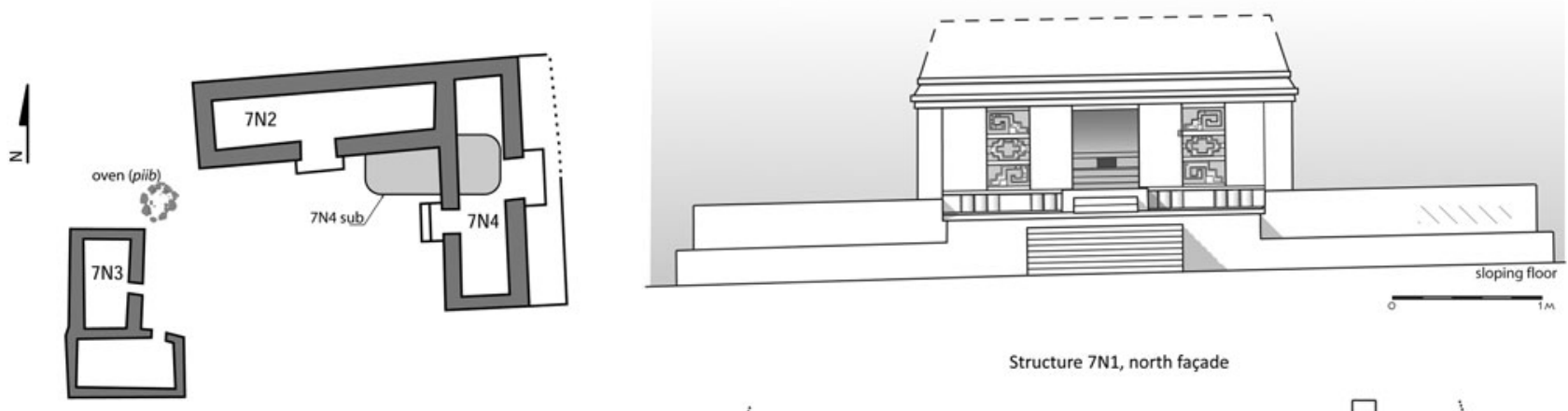

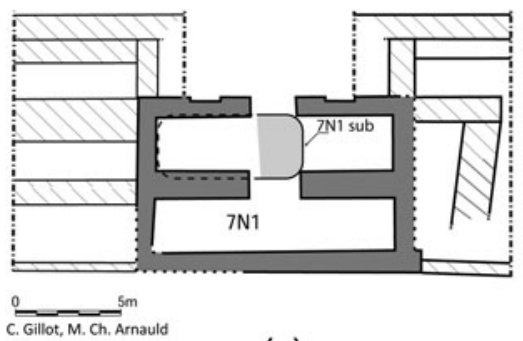

(a)

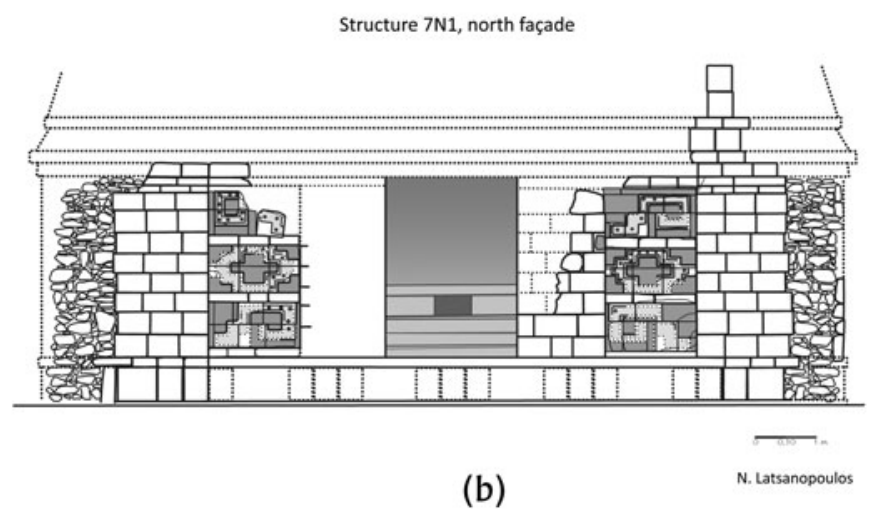

Figure 6. Río Bec, Group D Unit. General floor plan and façade elevation of its main residence, Structure 7N1. Plan by Céline Gillot and M. Charlotte Arnauld; drawing by Nicolas Latsanopoulos. 


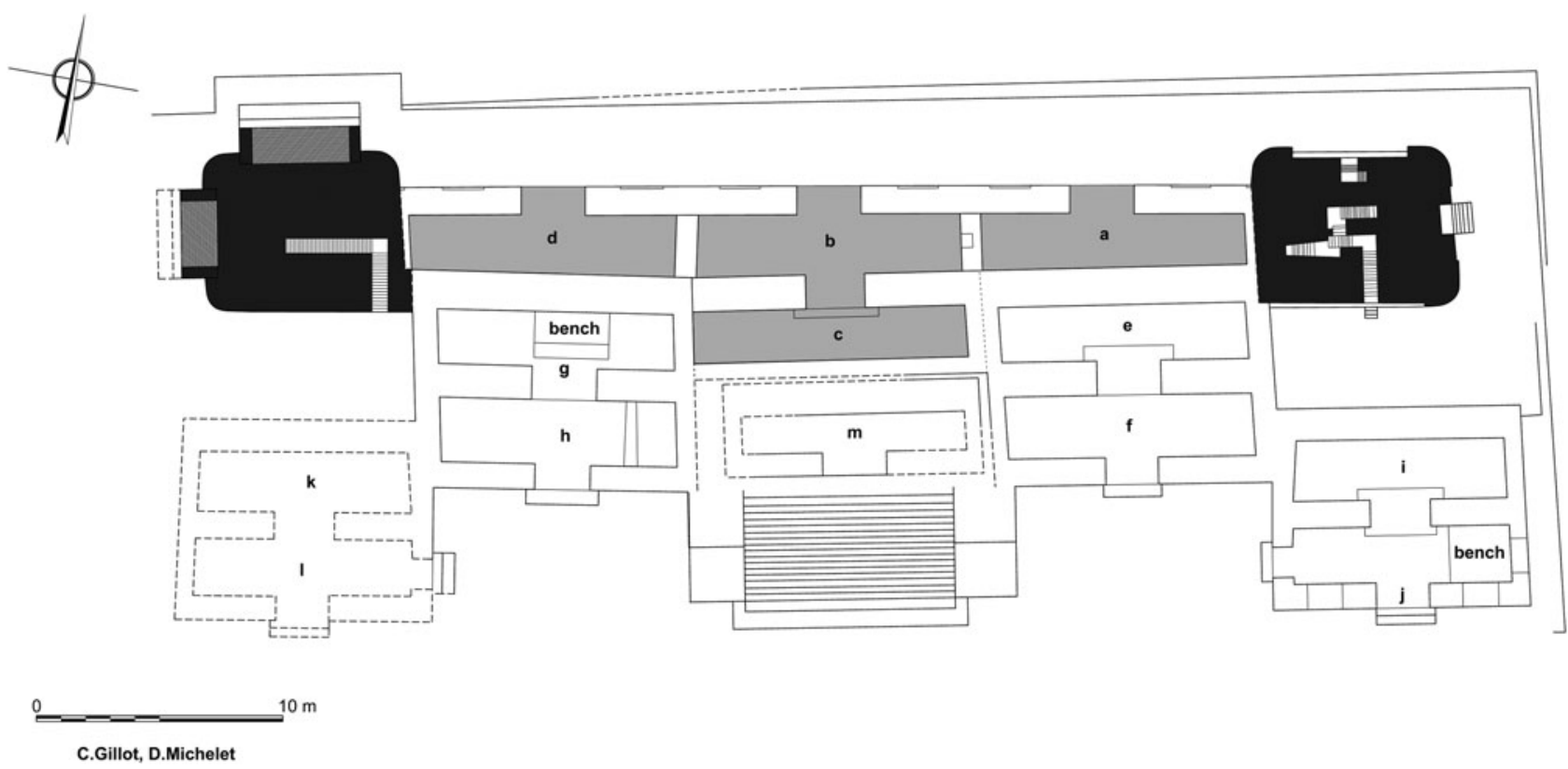

Figure 7. Río Bec, Group A, Structure 5N2. Massive towers are in black, unfinished rooms without constructed floors ("abcd”) in light grey; Room " $\mathrm{m}$ " is elevated on a high platform with a grand stairway; rooms "kl" were left unexcavated (see Michelet et al. 2013). Plan by Céline Gillot and Dominique Michelet.

Webster [2002:56]), making up what we call an "apartment." Multiroom residences were designed so that the more rooms or apartments they included, the more nuclear families they were able to house (Gonlin 2004:244; Kurjack 2003:275, 282; Terraciano 2001:200-201). In the structures we excavated, most of the inner rooms have masonry benches both wide and long enough to provide space for at least two adults. Curtain holders on each side of doorways are ubiquitous. If coresidence under the same roof was desired, as it seems to have been, a newly married couple had to dwell in one of the apartments. Thus, planning marriages must have been the main reason for modifying a house. Some peculiar details recorded in excavated structures suggest that residence expansion was actually planned in advance. In Unit D, Structure 7N1 (the dominant house) stands on a long basal platform leaving unoccupied, unfinished space on both sides, possibly in preparation for additional wings (Figure 6b). The expectation was correct since our excavations into both vacant sides revealed foundation walls (not deep enough to have contained the fill; see Figure 6a) preparing and outlining unrealized future rooms. On the main façade, on both sides at the ends of the basal molding, cut stones mark the exact place of the molding to be added if the wings had been built as planned. On both façade edges, the beautiful cut-stone veneer was left unfinished with a vertical band $.75 \mathrm{~m}$ wide made of rough stones up to the medial molding (Figure $6 \mathrm{~b}$ ). Such so-called unfinished façades are relatively common on Río Bec large-scale buildings, and it was not until the discovery of Structure 7N1's foundation walls and molding markers that we understood their function-that is, saving cut stones on parts that did not need them since they were to be covered by abutting walls for salient wings. No wings were built before the abandonment of Unit D by Xpuhuk 2 times (A.D. 900-950). Expansion had been planned, and claimed by means of façade details that most Maya insiders and outsiders understood, but was never carried out.
In other houses, partitions and doorways indicate that a division of the inner space was prepared to create more rooms (see Wilk 1988:143). In Structure 6N2's core front hall (Figure 3d), added partition walls built upon inner floors were detected, creating two additional rooms (North and South) with benches and access from the newly formed central vestibule. No doorways were opened on the façade, but in their place the façade shows one inset panel on each side of the vestibule axial door (Figure 8). Those panels are plain, while similar panels on three façades of Structure $6 \mathrm{~N} 1$ are decorated with the well-known Río Bec checkerboard motif (Figure 9) and still had their wooden lintels in situ, pointing to their virtual function of doorways. Hohmann (1998:Figure 61) has convincingly demonstrated that, in Becan Structure IV, the same panels (with wooden lintels and checkerboard decoration) are "flanking flat niches representing pseudo entrances," or virtual doorways ready to be opened. In Structure 6N2, at the moment one of the created rooms was closed definitively by sealing up its inner doorway, the corresponding outer panel on the front façade was also sealed up. Although opening all such panels would have damaged the structure stability, they stand signaling an ambition to expand the house-each panel meant a new room to be created and settled in, and a new family being founded. That the house was prepared to welcome new members is an interpretation consistent with the importance of growth in the social house model.

\section{FLOOR LEVELS AND ROOM SIZES: HOUSE RANKING}

All Río Bec dwelling units consist of a "dominant" house (Haviland 1985, 1988; Hendon 1991, 2007) and lesser houses, the difference being mainly one of size and decorative elaborateness. Even in one building, tripartite ground plan (Figure 3), stairways, and differences in floor levels suggest that some rooms or apartments had more prestigious occupants than others, as if the house itself was internally organized so as to combine coresidence with hierarchy 


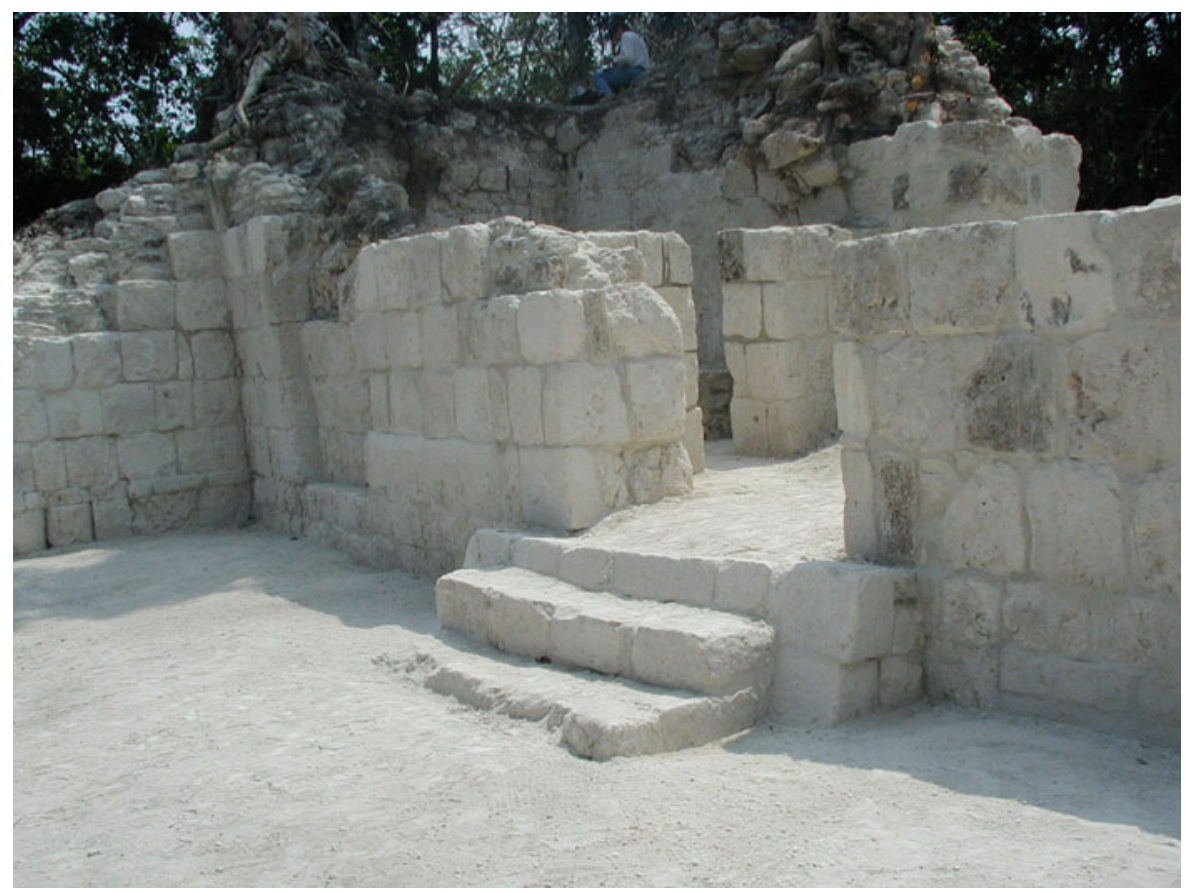

Figure 8. Río Bec, Group B, Structure 6N2 during 2003 excavations, with partial consolidation. Note the basal molding with embedded colonnettes, inset panels, axial doorway, and inner doorway leading to a lateral room. Photo courtesy of the Projet Río Bec.

and to allocate rank. The tripartite ground plan of many multiroom residences is better understood as a response to this need. Certainly not an innovation of Río Bec architecture, it existed already in Early Classic period palaces at Uaxactun (Valdés 2001:Figure 5.3), then developed in the Central Acropolis of Tikal, ("tandem-transverse plan" diagnostic of the residential function) (Harrison 1970, 1986), and was still the basic plan of the largest palaces at Uxmal by the Terminal Classic period (Kowalski 1987). It is common in many Río Bec sites. Even houses that were not strictly tripartite (meaning with transverse vaults) have three or five rooms in row (or six to ten in double rows). Rather than bilateral symmetry per $s e$, such layout was conceived of to emphasize centrality, a traditional plan that refers back to a number of symbolic triads in Maya cosmology (Christie 2003:309). Yet, as a pattern adapted to multiple nuclear family coresidency, the apt reference should be the patio-group developmental cycle of an extended family (Goody 1958; Haviland 1988; Tourtellot 1988a): the center $\operatorname{room}(s)$ equate(s) the fathers' house and the wings or lateral rooms those of the married sons (Arnauld and Michelet 2010). Tripartite ground plans and uneven numbers of rooms simply translated the family generation order and filiation principle relating fathers to their offspring, as well as the unequal (and then, unsymmetrical) relations of elder to younger brothers and daughters, determining the basic social ranking of generation and birth order. Along with the material correlates of continuity (see above), large-scale tripartite dwellings provide one of the best archaeological correlates for the ideological importance in Classic Maya society of lineages (Lévi-Strauss 1991:435), and possibly of patrilinearity (Hage 2003:15), even though it primarily reflects filiations rather than strict descent (Watanabe 2004).

Rear central rooms have the highest floor level within a building. Save for kitchens, all Río Bec large and small houses excavated so far have an inner floor higher than the outer floors. Within multi- room houses, rooms have their inner floors at different levels with an individual access stairway located in a conspicuous place (see Gonlin 2004:241). In apartments, the inner-room floor is always higher than the outer-room floor, but with a small space left at a lower level where visitors could stand in front of the host seated high on his bench. The evidence is suggestive of a deep concern about ranking among inhabitants and their visitors. This is supported by many scenes of residence interiors painted on ceramic vases, illustrating one paramount person seated on a bench with individuals standing or sitting below at distinct levels on steps figured by horizontal lines (Jackson 2009). Moreover, in Río Bec Groups B and D, several small- and medium-sized structures show successive modifications of inner floor levels in relatively short time periods (Structures 7N4, 7N3N, and 6N4E), suggesting that subtle adaptations were made to status changes caused by family cycle and/or marriages. The platforms of the paired tripartite house structures $6 \mathrm{~N} 1$ and $6 \mathrm{~N} 2$ are of the same height and their closest rooms have exactly the same inner floor level, yet Structure 6N1 (the house with towers) has basal-molding pseudo colonnettes much higher than those of Structure 6N2, giving the feeling that Structure 6N1 floors are higher (typically basal moldings mark the inner floor level) (Hohmann 1998:100). In this case the façade statement contradicts the real dimensions, suggesting that ambiguity was preferred.

Ground plan and floor levels are generally consistent with the rooms differing sizes. The Río Bec complete excavations of 23 structures of all sizes allow us to define three sizes of roofed surfaces: less than $12 \mathrm{~m}^{2}, 12-25 \mathrm{~m}^{2}$ and $25-39 \mathrm{~m}^{2}$. The smallest rooms correspond to small isolated houses (Structure $6 \mathrm{~N} 5,11 \mathrm{~m}^{2}$; Structure 7N63, $8 \mathrm{~m}^{2}$ and $5 \mathrm{~m}^{2}$; the latter shown in Figure 4), and to unvaulted, separate kitchens $\left(10-12 \mathrm{~m}^{2}\right)$. In large tripartite structures, the center room extends $25-39 \mathrm{~m}^{2}$, with side rooms covering from $12-25 \mathrm{~m}^{2}$. The smallest rooms in lone structures qualify as 


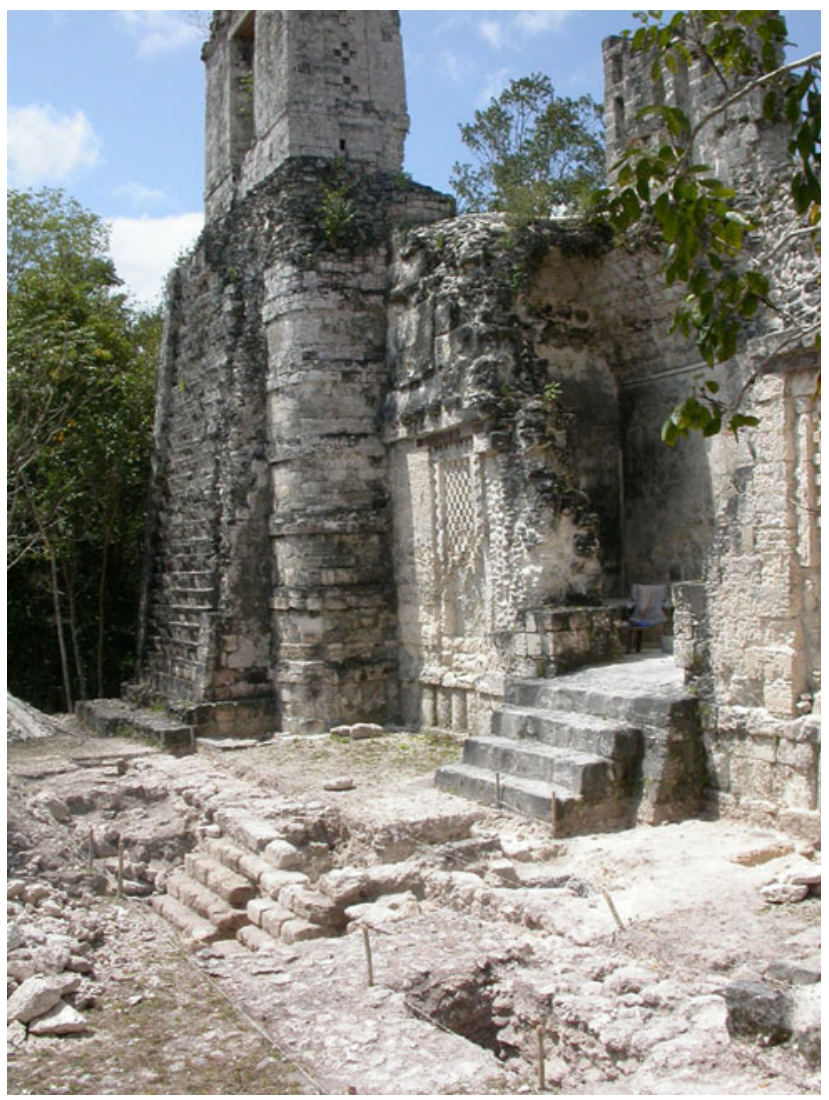

Figure 9. Río Bec, Group B, Structure 6N1 (excavated and restored by Prentice Thomas in 1976) during 2006 excavations south of the front platform. Note the basal molding with embedded colonnettes, inset panel with checker board decoration, and south tower with false staircase and temple. Photo courtesy of the Projet Río Bec.

simple dwelling quarters for the poorest peasants, while those included in large tripartite structures may have been used, instead, as storage space. Medium-sized rooms (12-25 $\mathrm{m}^{2}$ ) likely provided comfortable space for one nuclear family, and these rooms consistently have one ample bench abutting room walls. In large multiroom residences the center rooms are the largest. Hence they must have housed the head nuclear family and were logically also used as meeting halls due to both available space $\left(25-39 \mathrm{~m}^{2}\right)$ and presence of the leader. Thus, the house building not only distributes ranks among inhabitants-naturalizing status, since children dwelling in those houses need not be taught-it also measures a definite capacity of attraction or reception (people) and storage (wealth).

\section{STORAGE AND RECEPTION: HOUSE CAPACITY}

A house is a container with a definite interior volume to be filled with people and goods. Storage space is an important aspect of Río Bec architecture considering that wealth must have originated locally in agriculture (see Lemonnier and Vannière 2013). Staple storage (corn, beans, and perhaps cacao) must have required more space than tradable sumptuary items, but cloth and locally woven stuff may have been important too. Our main argument supporting residence storage functions, as discussed above, revolves around the size of small rooms (Gonlin 2004:229-231), and in some structures, their location adjacent to halls $\left(25-39 \mathrm{~m}^{2}\right)$ where supposedly tribute and gifts were displayed and exchanged (see below). If some speculation is allowed to further the storage issue, we suspect that some larger rooms built as housing quarters were used as specific storage space at least some time before they were occupied. Three rooms in the twin residences (Group B, Structures $6 \mathrm{~N} 1$ and $6 \mathrm{~N} 2$ ), and four rooms of the Structure 5N2 north façade were found "unfinished" (Michelet et al. 2013), that is, without any access stairway nor bench, and not even a stucco floor in the case of Structure $5 \mathrm{~N} 2$ north rooms (Figure 7). Structure $6 \mathrm{~N} 1$ and $6 \mathrm{~N} 2$ rooms received stairways and a bench during a later stage. The evidence of seven unfinished rooms (out of 52 rooms excavated) must be explained beyond anecdotal circumstances. We suggest that access stairways, stuccoed floors, and benches were considered by Maya elites as the equivalent of what we call "furniture" in our own Western dwellings (note that outset staircases generally abut platform walls in Maya architecture), and that ideally they were not built until weddings were negotiated and newly married youths ready to move in. Before this was achieved, "unfurnished" rooms could have been used as storage space, perhaps for wealth accumulated in preparation for the negotiation and feasting. The hypothesis is based on the social house model in which alliance and wealth are closely intertwined concerns for elites, and it may have some limited support from ethnohistory (see Terraciano [2001:238-239] for discussion of the Mixteca, as well as Gillespie and Joyce [1997] and Hendon [2000]).

The existence of long halls in multiroom residences ( $>$ $25-39 \mathrm{~m}^{2}$ in roofed surface, or longer than $10 \mathrm{~m}$ ) (see Figure 3b-3d) adequate for reception, meetings, and perhaps feasting is less speculative. Many such halls have been identified in the Maya area during the Classic and Postclassic periods, although generally as isolated structures of the gallery or "long-house" type (Arnauld 2001, 2002; Arnauld et al. 2004:111-115). At Río Bec, halls are more frequent as core rooms in tripartite residencessee, for example, Structures 6N1 and 6N2 in Group B (Figure 3), Group C (Figure 2), and Group M (Figure 1) —or as rooms on the public façade side of large residences, including Structure $5 \mathrm{~N} 2$ in Group A, and Groups J and L (Figure 2). In Group H, Structure 7M23 displays three long halls associated with small rooms (possibly storage rooms) making up a large U-shaped layout enclosing five dwelling rooms (Carrasco Vargas et al. 1986), all of which serve as outer public spaces shielding inner private spaces. In groups where separate kitchens can be identified, these are consistently located in association with the private side, that is, away from long halls (Groups A, B, L, H, K, J, and O). Hall sizes overlap with large dwelling room sizes (for example, in Groups A and D), as reception/meeting and dwelling functions were confounded in the case of the group leader (see Lyons 2007:183). Much variation existed among decisions made by local leaders when planning their residences, yet separate long houses emerged in some groups: including Group O, Structure 2; Group V, Structure III; and Kajtun Structures 42 and 43 (Figure 1) (Nondédéo and Lacadena 2004).

Only the most monumental units have several halls (Nondédéo et al. 2013), suggesting that the number and location of halls within units are a measure of their relevance as political locales. No material evidence for meeting or feasting practices was recovered, except for a sunken oven of the piib type-still used to cook meat in modern Yucatecan ritual feastings-discovered under the patio floor of Group D (Déodat and Arnauld 2012). At a place like Río Bec where public architecture is almost nonexistent, halls are features that must be given careful attention. In the case of 
Group B, the top-ranked unit has two paired, tripartite residences: Structure $6 \mathrm{~N} 1$ with two halls and Structure $6 \mathrm{~N} 2$ with one (Figure 3). In the latter, from the entranceway, small side steps give access to the raised floor in such a way that visitors may have been invited to climb and sit besides the host at the same level, as shown on some painted vases. There are no such steps in Structure $6 \mathrm{~N} 1$. Structure $6 \mathrm{~N} 2$ has no façade decoration, while Structure $6 \mathrm{~N} 1$ displays towers, roof comb and façade decoration. We suggest that there might be a correlation between interior features and exterior decoration so that Structure 6N2 was perhaps made to attract people within its interior, while Structure $6 \mathrm{~N} 1$ rather projected a prestigious image to outsiders. Enhancing the contrast between both structures, bench morphologies are analyzed below. Reception contexts appear to be of utmost importance in local domestic architecture.

\section{RECEPTION SCENERIES: HOUSE IDENTITY}

A number of Río Bec residential features can be interpreted in relation to a shared form of reception setting, which, however, also gives a definite identity to the house. In other words, all houses had a sort of "reception scenery" structured in much the same way, yet each physical house had its own individual character. The archaeologist has to work simultaneously with an overall pattern and a wide range of variability (Arnauld and Michelet 2010). Studied together, both help understand the cultural significance, symbolic expression and also functional logic of the reception scenery (Christie 2003; Harrison 2003; Kowalski 2003). Photo recording of dozens of Río Bec residences suggested to us that visibility both into inner rooms and onto exterior façades may have been important for Maya people (Arnauld and Michelet 2010; see also Demarest et al. [2003], concerning political architecture, and Inomata [2006], concerning public architecture). It should be noted that some Preclassic-to-Early Classic Maya buildings have offset entranceways and inner walls shielding the interior-as seen, for example, at Uaxactun, Nakbe, and Calakmul (Flannery 1998: Figure 2.9, Structure III; Hansen 1998:83; Schwarz 2009: 420-421) - while Late-Terminal Classic ones have axial openings into the inner rooms. We suggest that these were explicitly meaningful options.

The shared pattern refers to a reception, or presentation stage situated in what Giddens (1984:119-127) calls the house "front region for formalized social interaction" (for discussion of Maya houses see Christie 2003:310-311; Dahlin and Ardren 2002; Demarest et al. 2003:131-136; Harrison 1986, 2003; Harrison and Andrews 2004; Kowalski 1987, 2003; Valdés 2001:154-161; Webster 1989). In the Maya house, this included interaction spaces, such as the stairway, entranceway, and outer room, as well as the outer space, or pathway, that provides both a view of and an access to the house complete with the people and wealth it contained. Walking over this "reception scenery," the visitor looks at the entire façade up to the roof comb, if present (see Restall [2001:336-341] for a discussion of the Postclassic patio, plaza and tancabal; Ringle and Bey [2001:275] for discussion of a place designed for tribute presentation; Evans [2004:26, 47] for discussion of the Aztec palace "central courtyard"). In this view, the focus was the center bench, the person seated on it, and eventually the content of the bench lower niche (if present; see Figures 6, 11, 12). Framing this focus, horizontal and vertical components (both tripartite: wing/core/wing, basement/façade/roof) produce geometric scenery for the seated individual (note that Copan's
Structure 9N-82 1st had panels decorated with seated individuals [Fash 1989:Figure 64; see also Pereira [2013] for a discussion of the seating position). Moreover, included in the vision were meaningful elements like painted benches, stairways, floor levels, moldings with engaged colonnettes, inset panels, sculptured decoration, rough-stone sections (Figure 6b), and even in some cases, zoomorphic entranceways, towers with masks and roof comb. It is easy to evoke such grand reception sceneries as those of Becan Structure IV (north façade), Chicanna Structure XX, not to mention Xpujil or Hormiguero buildings, Río Bec Group I Structures XI and XVII, or Yaxek Structure 4 (Nondédéo and Patrois 2010). But probably less than one third of all multiroom buildings discovered so far in the $100 \mathrm{~km}^{2}$ micro-region were decorated (Nondédéo et al. 2013), and even houses with just one axial door in a plain façade, a raised inner-floor, and one central bench had an efficient reception scenery (Gonlin 2004:244). The pattern was not exclusive of the elite.

Once the pattern is defined, variation in details can be explored endlessly. Some houses have just plain inset panels, others have decorated panels with cut-stone checker board motifs (Structure B-6N1), steps and frets (Structure D-7N1; see Figure 6b) or other geometric, zoomorphic, or vegetation patterns (Structure A-5N2), whereas anthropomorphic designs are scarce, with many motifs being rather related to the Terrestrial Monster iconography (Baudez 2010; Michelet et al. 2013; Patrois 2013). Río Bec was an essentially rural settlement, and this Earth iconography may refer primarily to cultivated land marked by the house (Gillespie 2001:93-94; Patrois 2013:Figure 7b; Terraciano 2001:164). Elaborately decorated houses were made to be looked at as some sort of living Earth entity who owned a land estate, produced wealth, contained people, gave them unity, and allowed the group to reproduce and expand. Based on archaeological evidence, this definition is consistent with a number of ethnographic case studies (Carsten and Hugh-Jones 1995b:40, 42; Henderson and Ostler 2005:155; Lévi-Strauss 1982:174; McAnany 1995:97). We surmise that the family shrine would have been located in the central and most sacred reception scenery - the reason why no separate ritual structure exists in the Río Bec residential compounds, as discussed above (see Michelet et al. 2010). Reciprocally, in Maya Classic domestic clusters at least some so-called shrines may also have functioned as reception sceneries (see Sanders [1989:97] for discussion of temple and house functions at Copan). Altars are easily confused with benches.

\section{HOUSES WITHIN HOUSES: INTERIOR BENCHES}

While almost all masonry houses display reception scenery, not all had an inner bench built of masonry. A one-room house (Group D, Structure 7N2) shows an interior axial panel or niche set in the rear wall in which at least one adult can sit in front of the door; the feature has an associated graffiti stating this reception function (Figure 10a and 10b) (see also Patrois 2013:Figure 5c and 5d). Others possibly had a wooden bench on the raised floor. Some inner rooms have an entrance step decorated as an imitation of a wooden bench front with legs (Figure 11), and on façade, basalmolding colonnettes also recall the legs of a bench. Both features produce the optical effect that the whole house is set on a bench (molding) containing a bench (step) sustaining a bench (inner bench). In the 1970s at Copan, the highly decorated benches excavated in peripheral houses came as a surprise and a breakthrough in Maya studies of elites (Gillespie 2000c, 2001; Noble 1998; Webster 


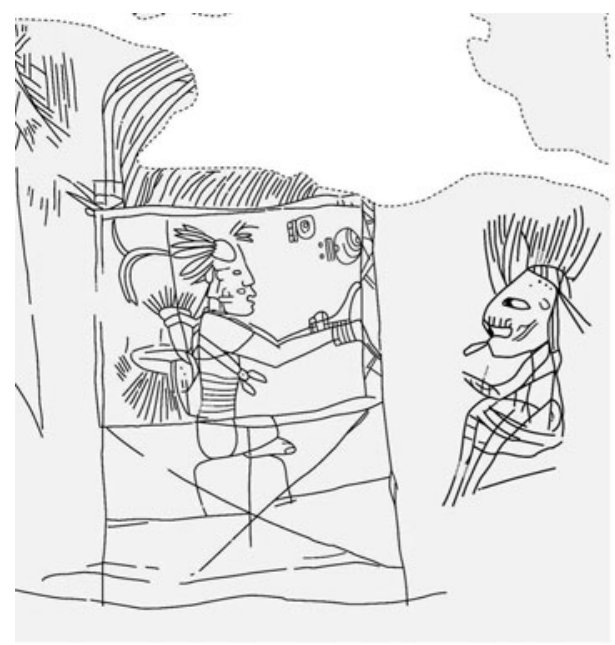

(a)

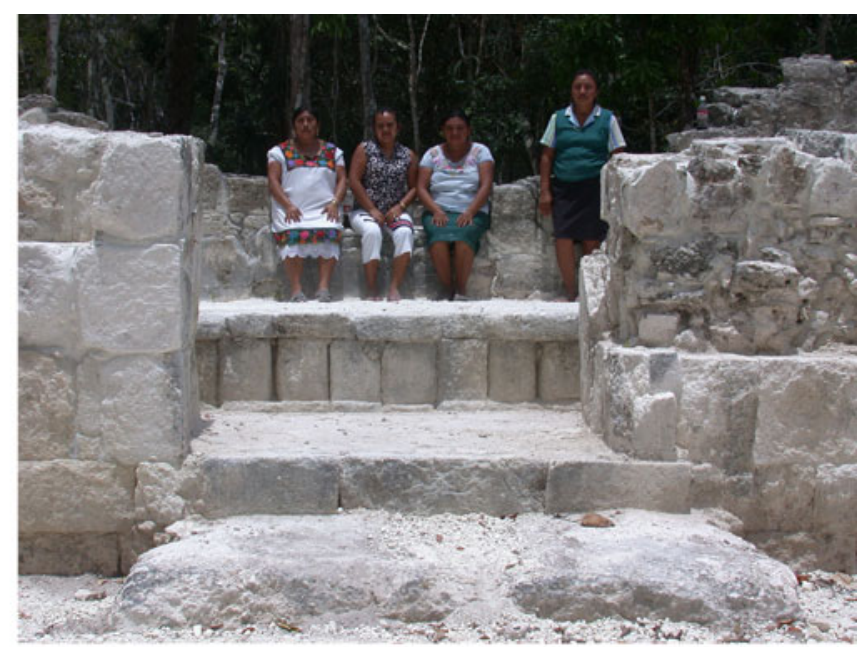

(b)

Figure 10. Río Bec, Group D, Structure 7N2 interior. (a) Graffiti found on the rear wall near the seat in photo; the host is seated left, drawn by an "experienced graffitist" (see Hutson 2011:413; Patrois 2013). The visitor is seated at the same level, drawn by a "beginner" with bigger head. (b) Ladies from Veinte de Noviembre village seated in the inset niche at the rear wall facing the axial doorway (note the raised floor front with embedded colonnettes). Photo courtesy of the Projet Río Bec.

1989:5-40; Webster and Abrams 1983; Webster and Inomata 2004: $153,169)$. Originally thought to be a trivial domestic feature, the central room bench appeared not different from a throne, yet displaying the identity of a non-royal family (see Terraciano 2001: 162).

Within Río Bec Structure 6N2, two benches in the core lateral rooms (South and North) (Figure 3) as well as the raised-floor front in the rear hall (West) were discovered with remains of painted glyphic inscriptions in blue, orange, green and black (on front stones) (Figure 12). The West and North inscriptions were preserved enough to be partially read (Arnauld and Lacadena 2004). The North one includes a Short Count calendar date (15 tuun 9 Ajaw) corresponding to A.D. 805, and a probable place name (kab'witz). The West one includes one name, probably an individual

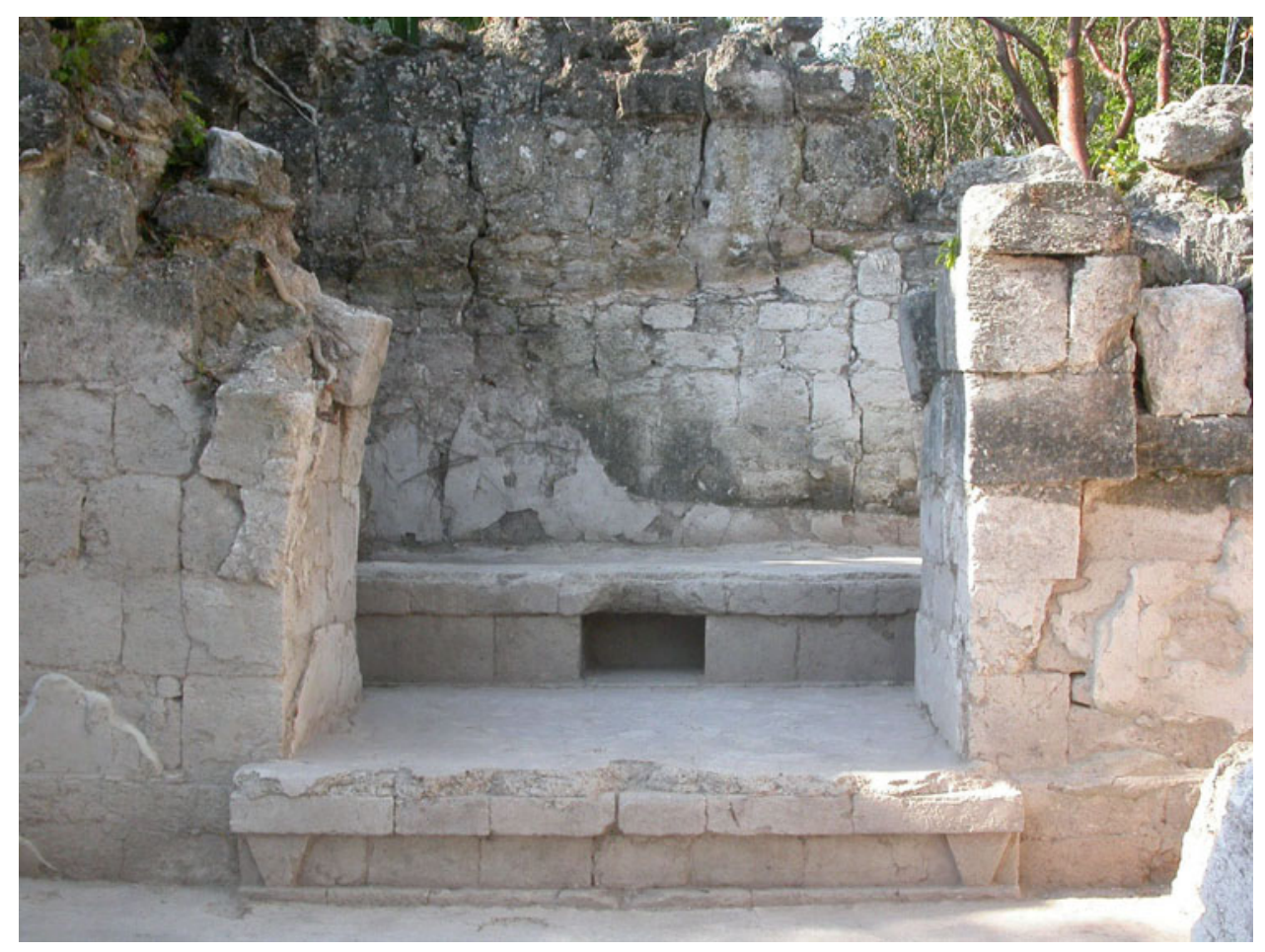

Figure 11. Río Bec, Group D, Structure 7N1. The step to the inner room is decorated with legs imitating a wooden bench. On its raised floor, the inner room has a masonry bench with a niche (before consolidation). Note curtain holders holes plugged on the sides of the doorway. Photo courtesy of the Projet Río Bec. 
name (Chan or Kan B'ohb' Tok'), and 'the house of' in Yucatec (yotoot). This is sufficient evidence to suggest that some specific identity was made public-perhaps "the house of Chan or Kan B'ohb' Tok"' (see McAnany and Planck 2000:99-101). These inscriptions may be compared to painted glyphs on benches in court scenes shown on ceramic vases, where they seem to provide the identity or status of the dominant individual seated on the bench (Jackson 2009; Reents-Budet 2001). Remember that in Structure 6N2, framing the West inscription, side steps were supposedly climbed by visitors invited to sit on the raised floor at both sides of their host (see above). The Structure 6N2 Room W is one of the longest halls at Río Bec $(14 \mathrm{~m})$, thus many people must have entered it, and read or seen the inscription. This West inscription was also visible from afar through both outer and inner doorways ( $2 \mathrm{~m}$ wide), while the side North and South benches were not visible from the exterior. In 2003, the West bench stones were not found in situ, but discovered vertically stored against walls in the South room and vestibule, while the South and North bench stones were in situ. When Structure 6N2 was abandoned, the inhabitants removed the West stones and hid them inside spaces invisible from the exterior, as they apparently did not want to leave such statements visible, perhaps in fear of some sorcery against themselves. The discovery of painted inscriptions on Structure 6N2 benches suggests that inner benches of many Río Bec buildings, either masonry or wooden ones, may have been equally painted with names and dates.

Below the front stones forming the seat, some benches have an open inner space, either a small rectangular niche, or more rarely a wider space with small columns sustaining the stones; for example, in Structure 6N2 (Figure 12), and in Structure 5N2's southeast room. Ceramic iconography suggests that such features were used to display goods exchanged between the individual seated on the bench and his visitors, or presented by them as gifts or tribute to him, in some cases as part of marriage negotiations (Reents-Budet 2001:213, 217). Visible from the outside, the content of the niche or lower space probably meant wealth of, and obligation vis-à-vis the social house. The lower spaces on benches from Structures $6 \mathrm{~N} 1$ and $6 \mathrm{~N} 2$ at Río Bec contained only a few large jar sherds (Thomas and Campbell 2008).

In Structure 6N2's lateral North and South rooms, the bench supports are preserved, and their carved and painted decoration give information about interactions that probably took place in the rooms. The four columns shaped as drums are carved in low relief showing typical court scenes in which a host is interacting with one person, possibly a visitor or guest (Figures 12 and 13; compare Structure 7N2 graffiti shown in Figure 10a). In all scenes, both men are seated at the same level, but the higher-rank individual is clearly indicated by his elaborate feather headdress and also, on three drums, by the presence in his back of a supernatural being seen in profile with a high vertical headdress and a curved nose forming a large hollow mouth or cavity, both traits that might represent the house as a personified being (high roof, inner space). If this interpretation were correct, the high-status individual would be the host seated in front of his house. Among the four guests, in the South room one offers to the host a round object (tamales? west drum), another proposes a mirror (east), and in the North room one is an old hunchback man (west) and the other a dwarf (east), both in conversation with their host. The latter figures are common in Maya Classic reception scenes (for example, the Kerr 1453 vase shown in Martin and Grube [2000: 15]). Because all individuals are seated at the same level, the four scenes can be said to pertain to the domestic sphere in which kin or insiders treated each other (almost) equally.

By contrast, the adjacent Structure 6N1 house has five masonry benches and none with a niche, save for the central one, which is much smaller than Structure $6 \mathrm{~N} 2$ niches. It is possible that the absence (or the small size) of niches correlates positively with façade elaborateness (see Mayer [1999] for an example from Chicanna). This would further the contrast already suggested between both houses: Structure 6N1 exhibits an outward decoration (towers with masks, roof comb, checker board panels) with relatively plain inner benches, although probably painted, whereas Structure $6 \mathrm{~N} 2$ had apparently no other decoration than its painted and carved benches in the interior. Our hypothesis is that the Structure 6N2 inhabitants would have dealt mostly with coresidents and insiders (inward interaction), the Structure 6N1 occupants mostly with higher-ranking outsiders (outward interaction). Both houses belonged to the same social group and were built roughly at the same time, with slightly different social functions, Structure $6 \mathrm{~N} 2$ fostering endogamic marriages, and Structure 6N1 exogamic alliances. We do not mean that this would describe exactly how real married people inhabited the houses, but rather that the paired houses would have reflected the principle of double alliance as a valued ambition-probably a conscious norm for the social group. Double dwellings would have conveyed distinct messages to distinct social levels. Also, possibly double dwellings per se, expressed the alliance linking autochtonous and allochtonous people, an old trope in Mesoamerican mythology.

\section{DISCUSSION: HOW TO DISCERN ALLIANCE IN ARCHITECTURE AND SETTLEMENT PATTERNS?}

To emphasize alliance means to envision not only marriage negotiation and ceremonies probably conducted within physical buildings, but also affinity relationships established between "foreign" and local social groups (Gillespie and Joyce 1997; Helms 1998). Alliance practices and representations structured ancient societies as much as, or even more than, filiation and descent concerns - but certainly less so in modern Western societies. Descent resulted in the splitting of groups and categorizing who belonged to what group, whereas alliance ensured growth as well as stable relationships with neighboring, foreign, or threatening groups, especially so for those polygynous households (Sanders 1989:96). The social house conceptually links both dynamics, alliance correcting the effects of descent and vice versa. Double alliance - " "to marry up and far away, to marry down and inside the local group" (Lévi-Strauss 1984:216)—allowed people of unequal ranks and distinct affiliations to intermarry frequently, building powerful groupings able to make up real political forces, an ambition much beyond "lineage perpetuation" (Sanders 1989:102-103). The main thrust of our argument is archaeological: in Classic Maya residential architecture, the general importance and variation of patterned reception settings must be interpreted in terms of the need to make alliances among hierarchized social groups, in all contexts from simple masonry houses up to royal reception rooms with thrones (the latter emphasized by Demarest et al. 2003; Harrison 2003; Valdés 2001). Obviously not restricted to the ajaw as a king, the reception scenery pattern was valid for any ajaw as head of a house. Every Maya ruler was also the head of his own house, be it his proper household, his larger (clan-like) grouping, his royal court, or even metaphorically the whole community of his subordinates. Agency in alliance making has social and political aspects (see Bricker 2002; Fox and Justeson 1986; Grube 

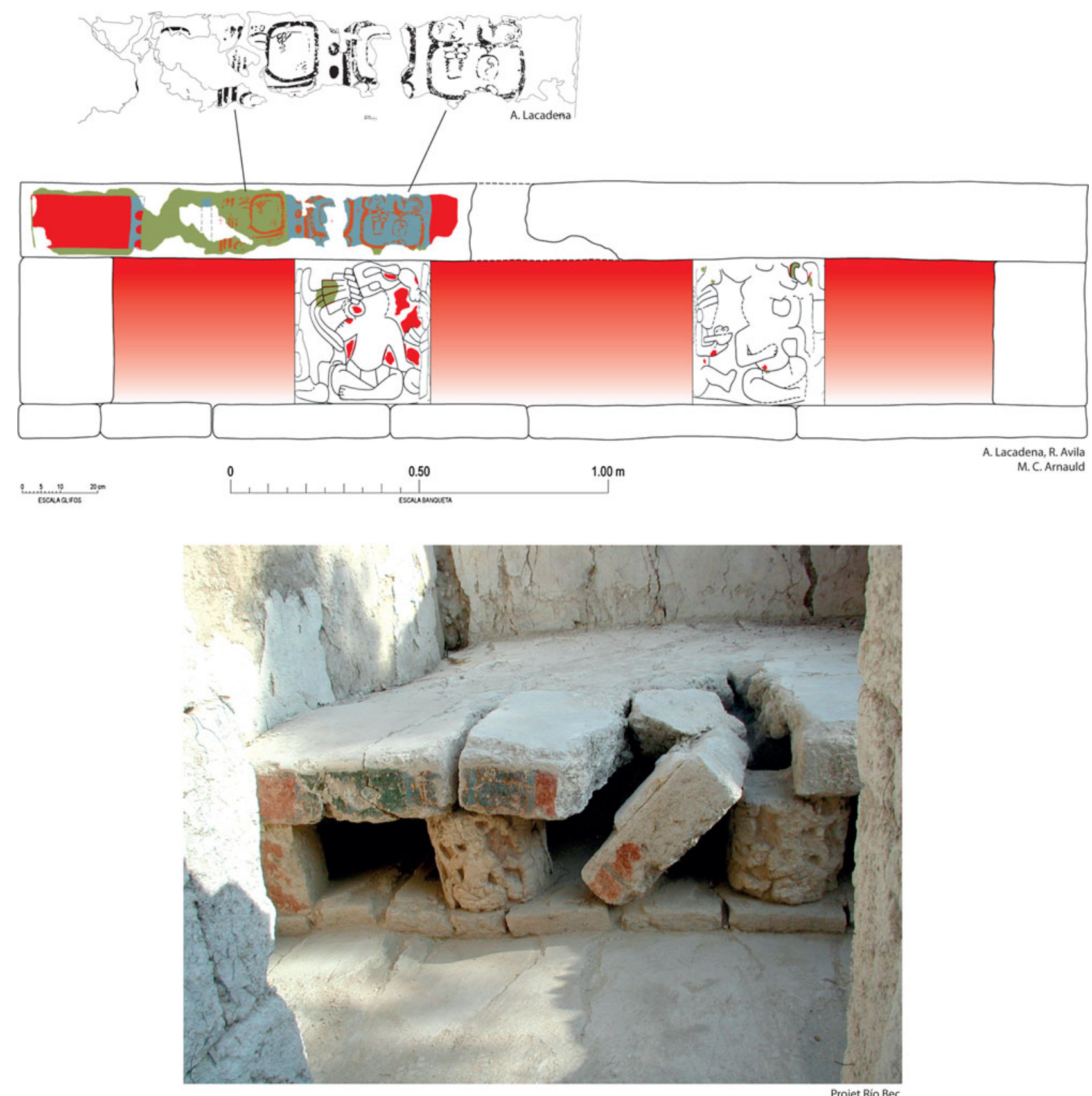

Figure 12. Río Bec, Group B, Structure 6N2. The core North room bench painted with glyphs. This bench can be seen at the Museo de la Arquitectura Maya, Baluarte de la Soledad, Campeche. Photo courtesy of the Projet Río Bec.

and Martin 1998; Hage 2003; Haviland 1977; Josserand and Hopkins 2002; Lincoln 2000; Marcus 1993, 1994, 1998; Munson and Macri 2009:436). A meaningful pun in Mixtec, the word tayu refers to "seat of authority" and "married ruling couple" (Terraciano 2001: 165). The archaeology of elite residences has long identified concerns revolving around identity, ancestral line, and wealth exhibition but, as Hirth pointed it (1992:25-28), these were basically the means of authentic politics of alliance. More concretely, several features of the Río Bec dwelling and settlement system can be tentatively examined in this perspective.

As shown in the present study of reception sceneries and meeting halls, outsiders were received in spaces close to, or uncomfortably within, the intimate sphere. This may be explained by the fact that, if many foreign visitors were possibly seen as potential affines, or in-laws (Terraciano 2001:172), they were treated as the insiders they might become some day. Even though high-rank marriage negotiations had political implications, they also involved basic domestic considerations. Likewise, the pervasive inside/ outside dichotomy in Río Bec multiroom houses should be considered in light of the alliance dilemma, that is, either exogamous or endogamous, either hypergamic or hypogamic links. Local grooms and brides were probably seen as lesser people in comparison with outsiders. Among coresidents, perceived differences between exogamic and endogamic couples must have been strong 


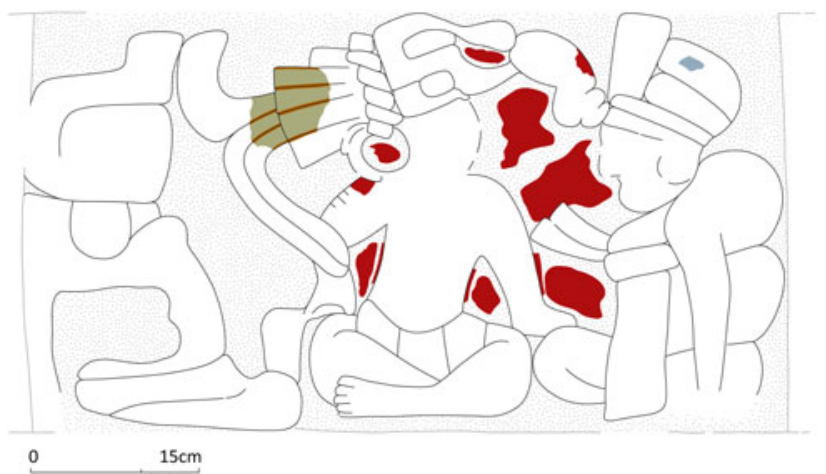

A. Lacadena, R. Avila, M. C. Arnauld north bench, west column

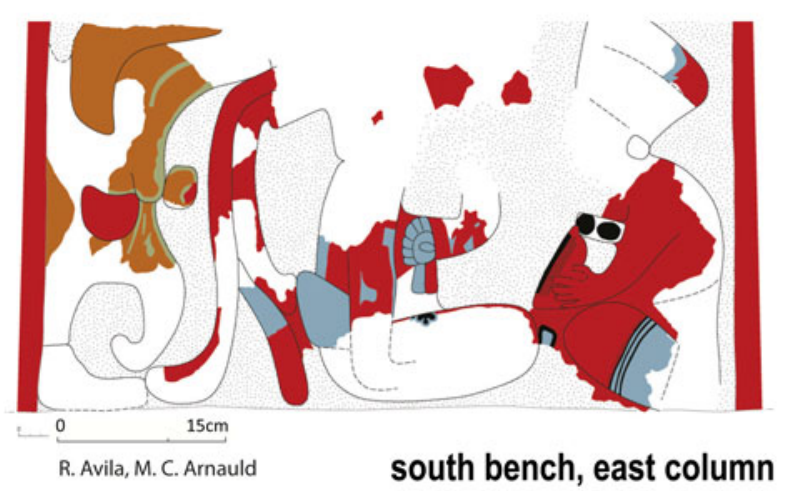

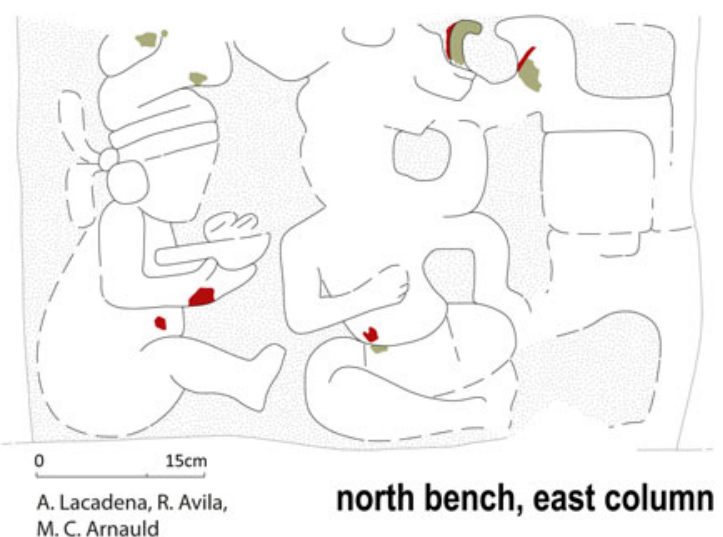

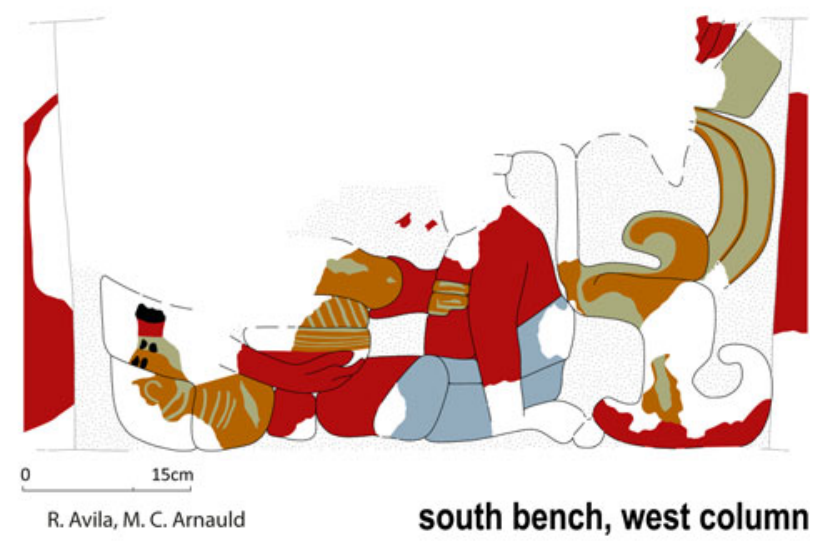

Río Bec Group B Structure 6N2

Figure 13. Roll-outs of the two pairs of sculptured and painted colonnettes supporting benches in the core North and South rooms in Group B, Structure $6 \mathrm{~N} 2$. In three of them, the supernatural entity is present behind the dominant individual. Rollouts prepared by Alfonso Lacadena, Rodolfo Avila, and M. Charlotte Arnauld.

in daily life. It is plausible to envision that higher-ranking nuclear families preferred to cluster in one house, leaving another residence for those "local" couples living together. This is the interpretation we suggest for the structural duality noted in Río Bec compounds, either as double buildings (for example, Structures 6N1 and 6N2 in Group B, or in Groups L and O), two-parts buildings (in Groups A and K) or other dual configurations (Groups D, H, and J). Given room layout and sizes, such duality cannot be explained entirely in terms of generation, nor gender (but see Hugh-Jones 1993:112). In one of his very few analyses of physical houses, Lévi-Strauss (1984:195-197, 1987) gave priority to the parameter of marriage practices in the case of Southeast Asia societies in which large, decorated multiroom buildings combine coresidence with hierarchy and descent rules.

In high-ranking houses, noble sons probably married high-status women from distant wards or cities, while their noble sisters would have married men of the local neighborhood (Helms 1998). The latter would account for some abandonment episodes that occurred in direct proximity to the groups we intensively excavated (Arnauld 2011; Nondédéo et al. 2013; Taladoire et al. 2013). Endogamic marriages (among other ties) with lesser-ranking households would have resulted in absorption of the corresponding units and their land into the neighboring, more affluent house. This was the way to appropriate much needed labor and land by "an all-encompassing social bonding" (McAnany 1993:78). According to Wilk (1988: 139-140), post-marital residence rules are of limited utility in Maya societies given that ethnohistorical and ethnographic sources do not indicate any constant pattern. On the one hand, virilocality (or patrilocality) would be more prevalent in areas where access to land is limited, as was probably the case locally. On the other, the well-known custom of bride service specifies that the newly married son-in-law moves into his wife s' paternal household for some time. As suggested by Hirth (1993:31), young couples tend to stay in the most affluent household. There is a good correlation between prosperity and the household size (Wilk 1988:140), and Río Bec was likely no exception.

Turning back to the Río Bec nuclear zone, one visible trend is that all Rank I units have a Rank I or II unit among their closest neighbors, resulting in a curious pattern of monumental-units pairing (Nondédéo et al. 2013): Group B with Group C (125 m), Group J with Group H $(<100 \mathrm{~m})$, and Group L with Group K $(<100 \mathrm{~m})$ (Figure 2). Considering the social heterogeneity across the settlement, this pattern is surprising. Although origins are poorly documented, all paired groups have similar building and occupation histories: The B-C paired group would have endured some 160 years (after the plausible hiatus in the Group $\mathrm{C}$ sequence), the H-J group pairing some 350 years, and the K-L group pairing some 250 years. In each pair one group did survive one or two generations 
longer than its supposed partner. Such enduring relationships involved a degree of competition and emulation, but also required much cooperation implying periodic renewal of matrimonial relationships through generations (Fox and Justeson 1986:28-29; Lévi-Strauss 1991:435). Repeated alliance resulting in group pairs and double alliance absorbing lesser-ranked dwelling units represent processes that would have helped form very cohesive and enduring social groupings. But admittedly much research on diachronic histories of neighboring dwelling units remains to be done in order to understand how both processes worked together (Arnauld 2011; Hutson et al. 2004:87-89; Kurjack 2006; Wilk 1988:146).

Finally, it is worth mentioning that independent data open the perspective of approaching exogamic links. Several specific cultural features like the Short Count date painted on one of the Structure $6 \mathrm{~N} 2$ benches, the associated inscription in Yucatec idiom, and one Fat God sculpture found at Kajtun point to the presence of northern lowland individuals or groups at Río Bec, reflecting some degree of intra-settlement cultural variability that one would not expect to find in lowland cities. Reciprocally, the diffusion of Río Bec residential architecture during the Late and Terminal Classic periods as far as El Tigre and Balamku to the west, Pechal to the north, Kohunlich to the east, and Calakmul to the southwest (Arnauld and Nondédéo 2010) may also be explained by elite alliance networks having developed and built up for two-to-three hundred years after the style emerged (A.D. 600-900). This reflects a dwelling system designed to favor alliance negotiation, and this style would have easily diffused by the very same mechanism of matrimonial links.

\section{CONCLUSION}

The social and economic trends implied in the endogamy/ exogamy pattern are deep and far-reaching. Lineage perpetuation was certainly basic, but growth mainly through alliance mechanisms was a far-reaching strategy of greater relevance. The economic sphere would have been structured by alliance practices and obligations in the absence of land or building-sale market, and of wage labor (Hirth 1992). Along with other investment in ritual and ceremonial expenditures, investment into alliances (matrimonial and political) must have been critical. Long-term double alliance and renewed alliances would have helped maintain social groupings (and reshape them) after cities collapsed, and this would explain much of the resilience shown by Maya social segments through time.

The focus on alliance may resolve a curious contradiction in Maya studies. On the one hand, since the 1990s, attention to diversity and variation in Maya regions has recently developed into a strong paradigm. On the other hand, the unity of Classic Maya civilization all over the lowlands is not really debated, and scholars readily resort to sweeping mechanisms to explain relatively rapid and generalized collapse by Terminal Classic period times, inferring that crisis transmission was efficient (see Marcus 2003:106). Webster (2002:135) has offered one partial way out of such awkward dilemma: "Many generations of intermarriages, alliances and visitations among ruling families had helped to disseminate widely the basic elements of the elite Great Tradition, including literacy, architectural styles, artistic conventions, standards of courtly behavior, political ideology, royal symbolism and burial practices."

The Río Bec evidence indicates that, first, the "many generations of intermarriages" linked not only "ruling families" but also noble houses marrying into many social ranks, thus reinforcing cultural unity. Second, they also fostered in every house the need for a distinctively expressed group identity (Bourdieu 1979), thus enhancing variability within and among Maya groupings. Centuries of alliance resulted in homogeneity and variation at different levels and scales in the Maya lowlands, something that should now be explored by giving attention to differing modes of agency in alliance making. Fortunately enough for archaeologists, alliance is mainly (but not only) a question of marriage, that is, a web of concrete issues directly and indirectly related to housing: to marry is also to get a separate house, or distinct dwelling quarters. Studies in architecture and settlement histories modeling alliance modes should be fruitful from such a perspective. As a measure of the importance attached to alliance making, houses built of cut stone were the investment that Río Bec peasants preferred to pyramid-temples with their elaborate burials reflecting descent concerns. They also invested into gardens and cultivated fields that contributed to the welfare of the house and conditioned its reproduction and growth (Lemonnier and Vannière 2013).

Alliance making may have been an important focus of kingly policies in Classic Maya cities, as some epigraphic evidence suggests (Marcus 1992). More attention should be given to the trivial fact that rulers generally controlled matrimonial alliances not only of their own houses, but also of their court members. In those Classic Maya cities that were governed by strong rulers, alliance formation and related agency may have been under their control (Sanders 1989:103). Reciprocally weak rulers had no control over alliance formation among their elites, except for the fact that being the apex of the ranking system, they formally warranted relationships among houses, something that eventually explained the late erection of stelae at Río Bec's already abandoned politico-religious groups, like Kajtun and Group II (Figure 1). Although much remains to be discovered about the local Río Bec political system, it is striking to discern, on one hand, weak kingship institutions and, on the other, autonomous noble houses that lavishly expressed their identity and apparently developed far-reaching alliance strategies. In many central lowland royal cities, stronger rulers may have forbidden similar expression and strategies.

\section{RESUMEN}

En las sociedades mayas clásicas, resulta difícil entender la articulación entre las varias partes que formaban juntas "el todo" de la comunidad, y/o la ciudad. La aproximación de este ensayo, basado en los resultados del proyecto Río Bec (2002-2010), consiste en analizar la arquitectura doméstica por medio de los conceptos de coresidencia y jerarquía social. Nos proponemos explorar los modos específicos de la convivencia "bajo el mismo techo" en una sociedad profundamente jerarquizada aún en el interior de los grupos de coresidencia. Cuando se identifican e interpretan correctamente en una muestra representativa de residencias, las variaciones arquitectónicas, modificaciones e innovaciones adquieren un significado en la medida en que llevan a resaltar no sólo conceptos fundamentales y necesidades sociales básicas, sino también algunas de las estrategias intencionalmente desarrolladas por los constructores y habitantes para establecer y mantener estatutos sociopolíticos.

En primer lugar, el estudio intenta mostrar que los conceptos de coresidencia y jerarquía ("de rangos" más que de clases o castas) pueden ser 
aplicados a las entidades mayas clásicas de las tierras bajas por medio del modelo de "sociedades de casa" (de Lévi-Strauss). En esta modelo, las unidades sociales intermedias estaban a la vez jerarquizadas internamente y fuertemente identificadas con su lugar de vida, i.e., con su edificio residencial. También se muestra que un principio ligado a la jerarquía social era la alianza desigual entre casas, o doble alianza- "por arriba" y "por abajo"entre nobles y gente del común. En segundo lugar se presenta una descripción sintética de las residencias mamposteadas excavadas y estudiadas en Río Bec, resaltando sus rasgos estructurales en relación a su permanencia y continuidad temporal, filiación, jerarquía, crecimiento del grupo e identidad.

Estos resultados preliminares permiten desarrollar el análisis de la arquitectura residencial de Río Bec (considerando edificios abovedados tanto grandes como modestos) en cuanto a rasgos evocando simbólicamente y prácticamente la permanencia del grupo (particularidades de los rellenos de basamentos), su crecimiento (plantas concebidas para adjuntar nuevas cámaras) y la jerarquía que imperaba dentro del grupo de coresidencia (por ejemplo, pisos interiores a distintos niveles). También se da particular atención a las dimensiones de cámaras que puedan indicar las condiciones de alojamiento de parejas, la necesidad de bodegas y la frecuencia de reuniones y posiblemente banquetes. Considerando la apertura del sistema residencial maya a las visitas de individuos externos al grupo de coresidencia, se analiza detenidamente las particularidades visuales de las fachadas de edificios, en las que resaltaba la banqueta central sobre la cual el jefe del grupo sentado recibía a dichos visitantes exteriores. Este "escenario de recepción" integraba detalles arquitectónicos significativos del estatuto, de la identidad y de las ambiciones propias de la casa como grupo de coresidencia. En particular se presentan casos excavados de banquetas pintadas con glifos, incluyendo una posible fecha calendárica de inauguración (805 d.C.), que expresarían las estrategias sociopolíticas del grupo local.

Considerando conjuntamente estos rasgos arquitectónicos significativos, se discute la hipótesis de que una de las estrategias para la adquisición de un alto rango en la jerarquía entre los grupos locales era, para cada casa, la de alianzas entre casas vecinas y con casas más lejanas. Mientras que las alianzas lejanas realzaban el prestigio de la casa, las alianzas locales aseguraban su crecimiento: datos cronológicos y espaciales observados en la zona nuclear de Río Bec sugieren que casas poderosas absorbieron familias vecinas de rangos inferiores. Del mismo modo, se aliaron entre sí, repitiendo la estrategia de alianza doble a través del tiempo y llegando a formar pares estables. También la presencia local de rasgos culturales exógenos, asi como la extraordinaria difusión regional del estilo Río Bec durante el clásico terminal, se podrían explicar por la repetición de alianzas lejanas.

\section{ACKNOWLEDGMENTS}

We thank all other project members, whose work, data and interaction have greatly contributed to our understanding of the residential system at Río Bec. We also thank Kenneth Hirth, Susan Gillespie, and Linda Manzanilla for their helpful comments on an earlier draft of this paper, as well as colleagues at Arizona State University who generously provided advice when the first

\section{REFERENCES}

Abrams, Elliot M.

1994 How the Maya Built Their World: Energetics and Ancient Architecture. University of Texas Press, Austin.

Adams, Richard E.W., and Robert C. Jones

1981 Spatial Patterns and Regional Growth among Classic Maya Cities. American Antiquity 46:301-322.

Andrews, E. Wyllys, V, and Barbara W. Fash

1992 Continuity and Change in a Royal Maya Residential Complex at Copan. Ancient Mesoamerica 3:63-88.

Andrieu, Chloé

2013 Late Classic Maya Lithic Production and Exchange in Río Bec and Calakmul, Mexico. Journal of Field Archaeology 38:21-37.

Annereau-Fulbert, Marie

2012 Intermediate Settlement Units in Late Postclassic Maya Sites in the Highlands: An Assessment from Archaeology and Ethnohistory. In The Neighborhood as a Social and Spatial Unit in Mesoamerican Cities, edited by M. Charlotte Arnauld, Linda R. Manzanilla, and Michael E. Smith, pp. 261-285. University of Arizona Press, Tucson.

Arnauld, M. Charlotte

1994 Légitimités mémoriales: Rois et caciques mayas du Guatemala entre 1540 et 1600. In Mémoires en devenir: Amérique latine $X V I^{e}-X X^{e}$ siècle, edited by François X. Guerra, pp. 63-83, Collection de la Maison des Pays Ibériques, Bordeaux.

1996 De Nacxit a Rabinal Achi: Estados territoriales en formación en las tierras altas mayas (posclásico). Investigadores de la Cultura Maya 3(2):231-268.

2001 La "casa grande": Evolución de la arquitectura del poder del clásico al postclásico. In Reconstruyendo la ciudad maya: El urbanismo en las sociedades antiguas, edited by Andrés Ciudad Ruiz, María Josefa Iglesias Ponce de León, and Maria del Carmen Martínez Martínez, pp. 363-401. Publicaciones de la S.E.E.M No. 6. Sociedad Española de Estudios Mayas, Madrid.

2002 Arquitectura política y residencial en La Joyanca, Noroccidente del Peten, (Guatemala). Mexicon 24(3):55-62.

2007 Imiter par soumission: Par défi ou par distinction? In Mobilités, immobilismes: L'emprunt et son refus, edited by Pierre Rouillard, Elizabeth Grimaud, and Catherine Perlès, pp. 235-251. author presented preliminary interpretations in a talk given at the School of Human Evolution and Social Change. Since 2002, the Río Bec project has received continuous support from the Instituto Nacional de Antropología e Historia de México (INAH). We also gratefully acknowledge the essential support of the local authorities and ejidatarios of Veinte de Noviembre.
Maison René-Ginouvès-Archéologie et Ethnologie, de Boccard, Paris.

2008 Maya Urbanization: Agrarian Cities in a Preindustrial World (Urbanización maya: Ciudades agrarias en un mundo pre-industrial). In Urbanism in Mesoamerica/El urbanismo en Mesoamerica, Vol. 2, edited by Alba Guadalupe Mastache, Robert H. Cobean, Angel García Cook, and Kenneth G. Hirth, pp. 1-36. Instituto Nacional de Antropología e Historia and the Pennsylvania State University, Mexico City and University Park.

2011 Fase y generación en la arquitectura residencial de Río Bec (Campeche). Paper presented at the 7th Mesa Redonda de Palenque "Los mayas y las concepciones del tiempo," Palenque.

Arnauld, M. Charlotte, and Alfonso Lacadena

2004 Asentar su autoridad: Banquetas en el Grupo B de Río Bec (Campeche, México). Journal de la Société des Américanistes 90(1): 203-222.

Arnauld, M. Charlotte, Véronique Breuil-Martinez, and Erick Ponciano A. (editors)

2004 La Joyanca (La Libertad, Guatemala): Antigua ciudad maya del noroeste del Peten. Centro de Estudios Mexicanos y Centroamericanos, Centro de Investigaciones Regionales de Mesoamerica, and the Asociación Tikal, Mexico and Guatemala.

Arnauld, M. Charlotte, and Dominique Michelet

2004 Nature et dynamique des cités mayas. Annales, Histoire, Sciences sociales 59(1):73-108.

2010 Casas monumentales de Río Bec, raíz del particularismo regional: Variantes and variaciones. In Figuras mayas de la diversidad, edited by Aurore Monod-Becquelin, Alain Breton, and Mario Ruz, pp. 409-431. Monografías del Centro peninsular en humanidades y ciencias sociales, Universidad Nacional de Autónoma de Mexico, Mérida.

Arnauld, M. Charlotte, Linda R. Manzanilla, and Michael E. Smith (editors) 2012 The Neighborhood as a Social and Spatial Unit in Mesoamerican Cities. University of Arizona Press, Tucson.

Arnauld, M. Charlotte, and Philippe Nondédéo

2010 Río Bec: Between the Central and the Northern Lowlands. In The Maya and Their Neighbours: Internal and External Contacts through 
Time, edited by Laura van Broekhoven, René Valencia R., Benjamin Vis, and Frauke Sachse, pp. 44-59. Acta Mesoamericana, Vol. 22. Verlag Anton Saurwein, Markt Schwaben.

Baudez, Claude F.

2010 La terre et ses masques. In Figuras mayas de la diversidad, edited by Aurore Monod-Becquelin, Alain Breton, and Mario H. Ruz, pp. 195-206. Monografías del Centro Peninsular en Humanidades y Ciencias Sociales, Universidad Nacional de Autónoma de Mexico, Mérida.

\section{Ball, Joseph}

1977 The Archaeological Pottery of Becan, Campeche, Mexico. Middle American Research Institute Publication No. 43. Tulane University, New Orleans.

Beck, Robin A., Jr

2007 The Durable House: Material, Metaphor and Structure. In The Durable House: House Society Models in Archaeology, edited by Robin A. Beck, pp. 3-24. Occasional Paper No. 35. Center for Archaeological Investigations, Southern Illinois University, Carbondale. Blanton, Richard E.

1994 Houses and Households: A Comparative Study. Plenum, New York.

Boas, Franz

1966 Kwakiutl Ethnography. Edited by Helen Codere. University of Chicago Press, Chicago.

Bourdieu, Pierre

1973 The Kabyle House. In Rules and Meanings: The Anthropology of Everyday Knowledge, edited by Mary Douglas, pp. 98-110. Penguin Books, Harmondsworth.

1977 Outline of a Theory of Practice. Translated by Richard Nice. Cambridge University Press, Cambridge.

1979 La distinction. Editions de Minuit, Paris.

Bowser, Brenda J., and John Q. Patton

2004 Domestic Spaces as Public Places: An Ethnoarchaeological Case Study of Houses, Gender, and Politics in the Ecuadorian Amazon. Journal of Archaeological Method and Theory 11:157-181.

Breuil-Martinez, Véronique, Eva Lemonnier, and Erick Ponciano A.

2004 Vivir en La Joyanca. In La Joyanca (La Libertad, Guatemala): Antigua ciudad maya del noroeste del Peten. edited by M. Charlotte Arnauld, Véronique Breuil-Martinez, and Erick Ponciano A., pp. 73-94. Centro de Estudios Mexicanos y Centroamericanos, Centro de Investigaciones Regionales de Mesoamerica, and the Asociación Tikal, Mexico and Guatemala.

Bricker, Victoria R.

2002 Evidencia de doble descendencia en las inscripciones de Yaxchilan and Piedras Negras. In La organización social entre los mayas: Memoria de la Tercera Mesa Redonda de Palenque, Vol. I, edited by Vera Tiesler Blos and Merle Greene Robertson, pp. 125-146. Instituto Nacional de Antropología e Historia and the Consejo Nacional para la Cultura y las Artes, Mexico City.

Canuto, Marcello A., and Jason Yaeger (editors)

2000 The Archaeology of Communities: A New World Perspective. Routledge, London.

Carballo, David

2009 Household and Status in Formative Central Mexico: Domestic Structures, Assemblages and Practices at La Laguna, Tlaxcala. Latin American Antiquity 20:473-501.

Carmean, Kelli

1991 Architectural Labor Investment and Social Stratification at Sayil, Yucatan, Mexico. Latin American Antiquity 2:151-165.

Carrasco Vargas, Ramón, Sylviane Boucher, and Agustín Peña Castillo

1986 Río Bec: Un modelo representativo del patrón de asentamiento regional. Boletín de la Escuela de Ciencias Antropológicas de la Universidad de Yucatan 14(78):20-29.

Carsten, Janet, and Stephen Hugh-Jones

1995a About the House: Lévi-Strauss and Beyond. Cambridge University Press, Cambridge.

1995b Introduction. In About the House: Lévi-Strauss and Beyond, edited by Janet Carsten and Stephen Hugh-Jones, pp. 1-46. Cambridge University Press, Cambridge.

Chance, John K.

2001 The Noble House in Colonial Puebla, Mexico: Descent, Inheritance, and the Nahua Tradition. American Anthropologist 102:485-502.

Chase, Arlen F., and Diane Z. Chase

1992 Mesoamerican Elites: Assumptions, Definitions and Models. In
Mesoamerican Elites: An Archaeological Assessment, edited by Diane Z. Chase and Arlen F. Chase, pp. 3-17. University of Oklahoma Press, Norman.

1996 More than Kin and King: Centralized Political Organization among the Late Classic Maya. Current Anthropology 37:803-810.

Chase, Diane Z., and Arlen F. Chase

2004 Archaeological Perspectives on Classic Maya Social Organization from Caracol, Belize. Ancient Mesoamerica 15:139-147.

Christie, Jessica J

2003 The Tripartite Layout of Rooms in Maya Elite Residences: Symbolic Centering, Ritual Mediating and Historical Governing. In Maya Palaces and Elite Residences: An Interdisciplinary Approach, edited by Jessica J. Christie, pp. 291-314. University of Texas Press, Austin.

Ciudad Ruiz, Andrés, María Josefa Iglesias Ponce de León, and Maria del Carmen Martínez Martínez (editors)

2001 Reconstruyendo la ciudad maya: El urbanismo en las sociedades antiguas. Publicaciones de la S.E.E.M No. 6. Sociedad Española de Estudios Mayas, Madrid.

Cuisenier, Jean

1992 La maison rustique. Presses Universitaires de France, Paris.

Dahlin, Bruce H., and Traci Ardren

2002 Modes of Exchange and Regional Patterns: Chunchucmil, Yucatan. In Ancient Maya Political Economies, edited by Marilyn A. Masson and David A. Freidel, pp. 249-284. AltaMira Press, Walnut Creek, CA.

Demarest, Arthur, Kim Morgan, Claudia Wolley, and Héctor Escobedo 2003 The Political Acquisition of Sacred Geography: The Murcielagos Complex at Dos Pilas. In Maya Palaces and Elite Residences: An Interdisciplinary Approach, edited by Jessica J. Christie, pp. 120-153. University of Texas Press, Austin.

Déodat, Laure, and M. Charlotte Arnauld

2012 Cocinas, comidas y convites en Río Bec. In Maya Daily Lives: Proceedings of the 13th European Maya Conference, edited by Philippe Nondédéo and Alain Breton, pp. 53-64. Acta MesoAmericana, Vol. 23. Verlag Anton Saurwein, Markt Schwaben.

Eaton, Jack D.

1975a Chicanna: An Elite Center in the Río Bec Region. Middle American Research Institute, Publication No. 31, pp. 133-138. Tulane University, New Orleans.

1975b Ancient Agricultural Farmsteads in the Río Bec Region of Yucatan. Contributions of the University of California Archaeological Research Facility 27:56-82.

Eeckhout, Peter

2010 How (Good) Was it to be the King? Current Research on the Archaeology of Palaces in Ancient America. Latin American Antiquity 21:459-466.

Elson, Christina M., and R. Alan Covey (editors)

2006 Intermediate Elites in Precolumbian States and Empires. University of Arizona Press, Tucson.

Evans, Susan T., and Joanne Pillsbury

2004 Palaces of the Ancient New World. Dumbarton Oaks, Washington, DC.

Farriss, Nancy M.

1984 Maya society under Colonial Rule: The Collective Enterprise of Survival. Princeton University Press, Princeton, NJ.

Fash, William L.

1983 Deducing Social Organization from Classic Maya Settlement Patterns: A Case Study from The Copan Valley. In Civilizations in the Ancient Americas: Essays in Honor of Gordon R. Willey, edited by Richard M. Leventhal and Alan L. Kolata, pp. 261-288. University of New Mexico Press and Peabody Museum of Archaeology and Ethnology, Harvard University, Albuquerque and Cambridge.

1989 The Sculptural Façade of Structure 9N82: Content, Form and Significance. In The House of the Bacabs, Copan, Honduras, edited by David Webster, pp. 41-72. Pre-Columbian Art and Archaeology Studies, No. 29. Dumbarton Oaks, Washington, DC.

1994 Changing Perspectives on Maya Civilization. Annual Review of Anthropology 23:181-208.

Flannery, Kent V.

1998 The Ground Plans of Archaic States. In Archaic States, edited by Gary M. Feinman and Joyce Marcus, pp. 13-58. School of American Research Press, Santa Fe. 
Fox, James A., and John S. Justeson

1986 Classic Maya Dynastic Alliance and Succession. In Ethnohistory, edited by Victoria R. Bricker, pp. 7-34. Supplement to the Handbook of Middle American Indians, Vol. 4, Ronald Spores, general editor, University of Texas Press, Austin.

Fox, John W., Garrett W. Cook, Arlen F. Chase, and Diane Z. Chase

1996 Questions of Political and Economic Integration. Current Anthropology 37:798-800.

Freter, AnnCorinne

2004 Multiscalar Model of Rural Households and Communities in Late Classic Copan Maya Society. Ancient Mesoamerica 15:93-106.

Fried, Morton

1967 The Evolution of Political Society. Random House, New York.

Giddens, Anthony

1984 The Constitution of Society: Outline of the Theory of Structuration. University of California Press, Berkeley.

Gillespie, Susan D.

2000a Rethinking Ancient Maya Social Organization: Replacing "Lineage" With "House." American Anthropologist 102:467-484.

2000b Levi-Strauss: Maisons and Sociétés à Maisons. In Beyond Kinship: Social and Material Reproduction In House Societies, edited by Rosemary A. Joyce and Susan D. Gillespie, pp. 23-52. University of Pennsylvania Press, Philadelphia.

2000c Maya "Nested Houses": The Ritual Construction of Place. In Beyond Kinship: Social and Material Reproduction in House Societies, edited by Rosemary A. Joyce and Susan D. Gillespie, pp. 135-160. University of Pennsylvania Press, Philadelphia.

2001 Personhood, Agency and Mortuary Ritual. Journal of Anthropological Archaeology 20:73-112.

2007 When is a House? In The Durable House: House Society Models in Archaeology, edited by Robin A. Beck, pp. 25-50. Center for Archaeological Investigations, Occasional Paper No. 35. Southern Illinois University, Carbondale.

Gillespie, Susan D., and Rosemary A. Joyce

1997 Gendered Goods: The Symbolical Maya Hierarchical Exchange Relations. In Women in Prehistory: North America and Mesoamerica, edited by Cheryl Claassen and Rosemary A. Joyce pp. 189-207. University of Pennsylvania Press, Philadelphia.

2000 Beyond Kinship: Social and Material Reproduction In House Societies. University of Pennsylvania Press, Philadelphia.

Gillot, Céline

2011 Étude des dimensions techniques et socio-économiques de la production architecturale à Río Bec (Campeche, Mexique), entre 600 et 1000 de l'ère courante. Ph.D. dissertation, Département d'Anthropologie, Université de Montréal, Montréal.

Godelier, Maurice

2004 Métamorphoses de la parenté. Fayard, Paris.

Gonlin, Nancy

2004 Methods for Understanding Classic Maya Commoners: Structure Function, Energetics, and More. In Ancient Maya Commoners, edited by Jon C. Lohse and Fred Valdez Jr., pp. 225-254. University of Texas Press, Austin.

Goody, Jack (editor)

1958 The Development Cycle in Domestic Groups. Cambridge Papers in Social Anthropology, No. 1. Cambridge University Press, New York.

Grube, Nikolai, and Simon Martin

1998 Política clásica maya dentro de una tradición mesoamericana: Un modelo epigráfico de organización política "hegemónica." In Modelos de entidades políticas mayas: Primer Seminario de Mesas Redondas de Palenque, edited by Silvia Trejo, pp. 131-146. Instituto Nacional de Antropología e Historia, Mexico City.

Hage, Per

2003 Ancient Maya Kinship System. Journal of Anthropological Research 59:5-21.

Hansen, Richard D.

1998 Continuity and Disjunction: The Pre-Classic Antecedents of Classic Maya Architecture. In Function and Meaning in Classic Maya Architecture, edited by Stephen D. Houston, pp. 49-122. Dumbarton Oaks, Washington, DC.

Harrison, Peter D.

1970 The Central Acropolis, Tikal, Guatemala: A Preliminary Study of the Functions of Its Structural Components during the Late Classic Period. Ph.D. dissertation, Department of Anthropology, University of Pennsylvania, Philadelphia.
1986 Tikal: Selected Topics. In City-States of the Maya: Art and Architecture, edited by Elizabeth P. Benson, pp. 45-71. Rocky Mountain Institute for Precolumbian Studies, Denver, CO.

2003 Palaces of the Royal Court at Tikal. In Maya Palaces and Elite Residences: An Interdisciplinary Approach, edited by Jessica J. Christie, pp. 98-119. University of Texas Press, Austin.

Harrison, Peter D., and E. Wyllys Andrews V

2004 Palaces of Tikal and Copan. In Palaces of the Ancient New World, edited by Susan T. Evans and Joanne Pillsbury, pp. 114-141. Dumbarton Oaks, Washington, DC.

Haumont, Bernard, and Alain Morel (editors)

2005 La Société des voisins: Partager un habitat. Éditions de la Maison des Sciences de l'Homme, Paris.

Haviland, William A.

1977 Dynastic Genealogies from Tikal, Guatemala: Implications for Descent and Political Organization. American Antiquity 42:61-67.

1985 Excavations in Small Residential Groups of Tikal: Groups 4F-1 And 4F-2. Tikal Report No. 19. University Museum Monographs No. 58. University Museum, University of Pennsylvania, Philadelphia.

1988 Musical Hammocks at Tikal: Problems with Reconstructing Household Composition. In Household and Community in the Mesoamerican Past, edited by Richard R. Wilk and Wendy Ashmore, pp. 121-135. University of New Mexico Press, Albuquerque. 1992 Status and Power in Classic Maya Society: The View from Tikal. American Anthropologist 94:937-940.

Helms, Mary

1998 Access to Origins: Affines, Ancestors and Aristocrats. University of Texas Press, Austin.

Henderson, Hope, and Nicholas Ostler

2005 Muisca Settlement Organization and Chiefly Authority at Suta, Valle de Leyva, Colombia: A Critical Appraisal of Native Concepts of House for Studies of Complex Societies. Journal of Anthropological Archaeology 24:148-178.

Hendon, Julia

1991 Status and Power in Classic Maya Society. American Anthropologist 93:894-918.

1996 Archaeological Approaches to the Organization of Domestic Labor: Household Practice and Domestic Relations. Annual Review of Anthropology 25:45-61.

1999 The Pre-Classic Maya Compound as the Focus of Social Identity. In Social Patterns in Pre-Classic Mesoamerica, edited by David C. Grove and Rosemary A. Joyce, pp. 97-125. Dumbarton Oaks, Washington, DC

2000 Having and Holding: Storage, Memory Knowledge and Social Relations. American Anthropologist 102:42-53.

2007 Memory, Materiality, and Practice: House Societies in Southeastern Mesoamerica. In The Durable House: House Society Models in Archaeology, edited by Robin A. Beck, pp. 292-316. Center for Archaeological Investigations, Occasional Paper No. 35. Southern Illinois University, Carbondale.

2012 Neighborhoods in Prehispanic Honduras: Settlement Patterns and Social Groupings within Sites or Regions. In The Neighborhood as a Social and Spatial Unit in Mesoamerican Cities, edited by M.Charlotte Arnauld, Linda R. Manzanilla, and Michael E. Smith, pp. 159-180. University of Arizona Press, Tucson.

Hill, Robert M., II, and John Monaghan

1987 Continuities in Highland Maya Social Organization: Ethnohistory in Sacapulas, Guatemala. University of Pennsylvania Press, Philadelphia.

Hillier, Bill, and Julienne Hanson

1984 The Social Logic of Space. Cambridge University Press, Cambridge.

Hirth, Kenneth

1992 Interregional Exchange as Elite Behavior: An Evolutionary Perspective. In Mesoamerican Elites: An Archaeological Assessment, edited by Diane Z. Chase and Arlen F. Chase, pp. 18-29. University of Oklahoma Press, Norman.

1993 The Household as an Analytical Unit: Problems in Method and Theory. In Prehispanic Domestic Units in Western Mesoamerica: Studies of Household Compound and Residence, edited by Robert S. Santley and Kenneth G. Hirth, pp. 21-36. CRC Press, Boca Raton, FL. Hohmann, Hasso

1998 A Maya Palace in Mexico: Structure IV at Becan, Campeche. Academic Publishers, Graz. 
Houston, Stephen D., and Patricia A. McAnany

2003 Bodies and Blood: Critiquing Social Construction in Maya Archaeology. Journal of Anthropological Archaeology 22:26-41.

Houston, Stephen D., and David Stuart

2001 Peopling the Classic Maya Court. In Royal Courts of the Ancient Maya, Vol. 2, edited by Takeshi Inomata and Stephen D. Houston, pp. 54-83. Westview Press, Boulder, CO.

Hugh-Jones, Stephen

1993 Clear Descent or Ambiguous Houses? A Re-Examination of Tukanoan Social Organisation. L'Homme 33(126):95-120.

Hutson, Scott R.

2011 The Art of Becoming: The Graffiti of Tikal, Guatemala. Latin American Antiquity 22:403-426.

Hutson, Scott R., Aline Magnoni, and Travis W. Stanton

2004 House Rules? The Practice of Social Organization in Classic Period Chunchucmil, Yucatan, Mexico. Ancient Mesoamerica 15:75-92.

Iannone, Gyles

2002 Annales, History and the Ancient Maya State: Some Observations on the "Dynamic Model." American Anthropologist 104:68-78.

Iannone, Gyles, and Samuel V. Connell

2003 Perspectives on Ancient Maya Rural Complexity. The Cotsen Institute of Archaeology, Monograph No. 49. University of California, Los Angeles.

Inomata, Takeshi

2006 Plazas, Performers, and Spectators: Political Theaters of the Classic Maya. Current Anthropology 47:805-842.

Inomata, Takeshi, and Stephen D. Houston (editors)

2000 Royal Courts of the Ancient Maya, Vol. 1: Theory, Comparison, and Synthesis. Westview Press, Boulder, CO.

2001 Royal Courts of the Ancient Maya, Vol. 2: Data and Case Studies. Westview Press, Boulder, CO.

Jackson, Sarah E.

2009 Imagining Courtly Communities: An Exploration of Classic Maya Experiences of Status and Identity through Painted Ceramic Vessels. Ancient Mesoamerica 20:61-85.

Josserand, J. Kathryn, and Nicholas A. Hopkins

2002 Classic Maya Social Interaction and Linguistic Practice: Evidence from Hieroglyphic Inscriptions and Mayan Languages. In $\mathrm{La}$ organización social entre los mayas: Memoria de la Tercera Mesa Redonda de Palenque, Vol. 2, edited by Vera Tiesler Blos, Rafael Cobos, and Merle Greene Robertson, pp. 355-372. Instituto Nacional de Antropología e Historia, Mexico City.

Joyce, Rosemary A.

2000 Heirlooms and Houses: Materiality and Social Memory. In Beyond Kinship: Social and Material Reproduction in House Societies, edited by Rosemary A. Joyce and Susan D. Gillespie, pp. 189-212. University of Pennsylvania Press, Philadelphia.

Kent, Susan (editor)

1990 Domestic Architecture and the Use of Space: An Interdisciplinary Cross-Cultural Study. Cambridge University Press, Cambridge.

Kintz, Ellen R.

1983 Neighborhoods and Wards in a Classic Maya Metropolis. In Coba: A Classic Maya Metropolis, edited by William J. Folan, Ellen R. Kintz, and Laraine A. Fletcher, pp. 179-190. Academic Press, New York.

Kowalski, Jeffrey K

1987 The House of the Governor: A Maya Palace of Uxmal, Yucatan, Mexico. University of Oklahoma Press, Norman.

1999 Mesoamerican Architecture as a Cultural Symbol. Oxford University Press, New York, Oxford.

2003 Evidence for the Functions and Meanings of Some Northern Maya Palaces. In Maya Palaces and Elite Residences: An Interdisciplinary Approach, edited by Jessica J. Christie, pp. 204-252. University of Texas Press, Austin.

Kurjack, Edward B.

1974 Prehistoric Lowland Maya Community and Social Organization: A Case Study at Dzibilchaltun, Yucatan, Mexico. Middle American Research Institute, Publication No. 38. Tulane University, New Orleans.

2003 Palace and Society in the Northern Maya Lowlands. In Maya Palaces and Elite Residences: An Interdisciplinary Approach, edited by Jessica J. Christie, pp. 274-290. University of Texas Press, Austin.

2006 Las alianzas matrimoniales entre los mayas y los origines de la complejidad social. Paper presented at the 52nd International Congress of Americanists, Seville.
Lemonnier, Eva

2009 La structure de l'habitat du site maya classique de La Joyanca dans son environnement local (Peten, Guatemala). Paris Monographs in American Archaeology No. 23. BAR International Series 2016. Archaeopress, Oxford.

Lemonnier, Eva, and Boris Vannière

2013 Agrarian Features, Farmsteads, and Homesteads in the Río Bec Nuclear Zone, Mexico. Ancient Mesoamerica 24:397-413.

Lévi-Strauss, Claude

1979 La voie des masques. Plon, Paris.

1982 The Way of the Masks. Translated by Sylvia Modelski. Washington University Press, Seattle.

1984 Paroles données. Plon, Paris.

1987 Anthropology and Myth: Lectures, 1951-1982. Translated by Roys Willis. Basil Blackwell, Oxford.

1991 Maison. In Dictionnaire de l'Ethnologie et de l'Anthropologie, edited by Pierre Bonte and Michel Izard, pp. 434-436. Presses Universitaires de France, Paris.

Liendo Stuardo, Rodrigo

2003 Access Patterns in Maya Royal Precincts. In Maya Palaces and Elite Residences: An Interdisciplinary Approach, edited by Jessica J. Christie, pp. 184-203. University of Texas Press, Austin.

Lincoln, Elena K.

2000 Yucatec Maya Marriage and Political Alliances. Ph.D. dissertation, Department of Anthropology, University of California, Los Angeles.

Lohse, Jon C., and Fred Valdez Jr. (editors)

2004 Ancient Maya Commoners. University of Texas Press, Austin.

Lucero, Lisa J.

2003 Politics of Ritual: The Emergence of Classic Maya Rulers. Current Anthropology 44:523-558.

Lyons, Diane E.

2007 Building Power in Rural Hinterlands: An Ethnoarchaeological Study of Vernacular Architecture In Tigray, Ethiopia. Journal of Archaeological Method and Theory 14:179-207.

McAnany, Patricia A.

1993 The Economics Of Social Power And Wealth Among Eighth-century Maya Households. In Lowland Maya Civilization in the Eighth Century A.D., edited by Jeremy A. Sabloff and John S. Henderson, pp. 64-90. Dumbarton Oaks, Washington, DC.

1995 Living with the Ancestors: Kinship and Kingship in Ancient Maya Society. University of Texas Press, Austin.

1998 Ancestors and the Classic Maya Built Environment. In Function and Meaning in Classic Maya Architecture, edited by Stephen D. Houston, pp. 271-298. Dumbarton Oaks, Washington, DC.

McAnany, Patricia, and Shannon Plank

2000 Perspectives on Actors, Gender Roles and Architecture. In Royal Courts of the Ancient Maya, Vol. 1: Theory, Comparison, and Synthesis, edited by Takeshi Inomata and Stephen D. Houston, pp. 84-129. Westview Press, Bouder, CO.

Macdonald, Charles (editor)

1987 De la hutte au palais, société “à maison” en Asie du Sud-Est insulaire. Centre National de la Recherche Scientifique, Paris.

McKinnon, Susan

2000 The Tanimbarese Tavu: The Ideology of Growth and the Material Configurations of Houses and Hierarchy in an Indonesian Society. In Beyond Kinship: Social And Material Reproduction in House Societies, edited by Rosemary A. Joyce and Susan D. Gillespie, pp. 161-176. University of Pennsylvania Press, Philadelphia.

Manzanilla, Linda R., and Claude Chapdelaine (editors)

2009 Domestic Life in Prehispanic Capitals: A Study in Specialization, Hierarchy, and Ethnicity. Memoirs of the Museum of Anthropology, No. 46. Studies in Latin American Ethnohistory and Archaeology, Vol. 7, Joyce Marcus, General Editor. University of Michigan, Ann Arbor.

Marcus, Joyce

1992 Mesoamerican Writing Systems: Propaganda, Myths, and History in Four Ancient Civilizations. Princeton University Press, Princeton, NJ.

1993 Ancient Maya Political Organization. In Lowland Maya Civilization in the Eighth Century A.D., edited by Jeremy A. Sabloff and John S. Henderson, pp. 111-183. Dumbarton Oaks, Washington, DC.

1994 Political Fluctuations in Mesoamerica. National Geographic Research and Exploration 8(4):392-411. 
1998 Peaks and Valleys of Ancient States: An Extension of the Dynamic Model. In Archaic States, edited by Gary M. Feinman and Joyce Marcus, pp. 59-94. School of American Research Press, Santa Fe.

2000 Toward an Archaeology of Communities. In The Archaeology of Communities: A New World Perspective, edited by Marcello A. Canuto and Jason Yaeger, pp. 231-242. Routledge, London.

2003 Recent Advances in Maya Archaeology Journal of Archaeological Research 11(2):71-148.

2004 Maya Community: Stereotype and Reality. In Ancient Maya Commoners, edited by Jon C. Lohse and Fred Valdez Jr., pp. 255-284. University of Texas Press, Austin.

Marcus, Joyce, and Jeremy A. Sabloff

2008 The Ancient City: New Perspectives on Urbanism in the Old and New World. School of American Research Press, Santa Fe.

Martin, Simon

2000 Court and Realms: Architectural Signatures in the Classic Maya Southern Lowlands. In Royal Courts of the Ancient Maya, Vol. 1: Theory, Comparison, and Synthesis, edited by Takeshi Inomata and Stephen D. Houston, pp. 168-194. Westview Press, Boulder, CO.

Martin, Simon, and Nikolai Grube

2000 Chronicle of the Maya Kings and Queens. Thames and Hudson, New York.

Mastache, Alba Guadalupe, Robert H. Cobean, Angel García Cook, and

Kenneth G. Hirth (editors)

2008 Urbanism in Mesoamerica/El urbanismo en Mesoamerica, Vol. 2. Instituto Nacional de Antropología e Historia and the Pennsylvania State University, Mexico City and University Park.

Mauclaire, Simone

1996 La construction du rôle du père à l'apogée de l'aristocratie de la cour de Heian (Xe-Xie siècle). L'Homme 36(140):25-61.

Mauzé, Marie

1986 Boas, les Kwagul et le Potlatch. L'Homme 26(100):21-63.

Mayer, Karl Herbert

1999 Bench Decorations of Structure XX, Chicanna, Campeche. Baessler-Archiv, Neue Folge, Band XLVII:323-343.

Michelet, Dominique, Philippe Nondédéo, Julie Patrois, Céline Gillot, and Emyly González G.

2013 Structure 5N2 ("Group A"): A Río Bec Paradigmatic Palace? Ancient Mesoamerica 24:415-431.

Michelet, Dominique, Philippe Nondédéo, Grégory Pereira, Julie Patrois, M.

Charlotte Arnauld, and Alfonso Lacadena García-Gallo

2010 Rituales en una sociedad "sin" reyes: El caso de Río Bec y del Edificio A (5N2) en particular. In El ritual en el mundo maya: De lo privado a lo público, edited by Andrés Ciudadz, Rui, María Josefa Iglesias Ponce de León, and Miguel Sorroche Cuerva, pp. 153-180. Publicaciones de la S.E.E.M., No. 9. Sociedad Española de Estudios Mayas, Madrid.

Monaghan, John

1996 The Mesoamerican Community as a "Great House." Ethnology 35:181-194.

Munson, Jessica L., and Martha J. Macri

2009 Sociopolitical Network Interactions: A Case Study of the Classic Maya. Journal of Anthropological Archaeology 28:424-438.

Neurath, Johannes

2000 La maison de Levi-Strauss and la Casa Grande wixarika. Journal de la Société des Américanistes 86:113-128.

Noble, Sandra E.

1998 Mayas Seats and Maya Seats Of Authority. Ph.D. Dissertation, Department of Anthropology, University of British Columbia, Vancouver.

Nondédéo, Philippe, M. Charlotte Arnauld, and Dominique Michelet

2013 Río Bec Settlement Patterns and Local Sociopolitical Organization. Ancient Mesoamerica 24:373-396.

Nondédéo, Philippe, and Alfonso Lacadena

2004 Kajtun: Un nuevo sitio maya con monumentos esculpidos en la región Río Bec. Journal de la Société des Américanistes 90: 183-201

Nondédéo, Philippe, and Julie Patrois

2010 Variaciones en la morfología y la decoración de los edificios mayores de Río Bec: En busca de un significado. In Figuras mayas de la diversidad, edited by Aurore Monod-Becquelin, Alain Breton, and Mario Ruz, pp. 305-334. Monografías del Centro peninsular en humanidades y ciencias sociales, Universidad Nacional de Autónoma de México, Mérida.
Okoshi Harada, Tsubasa

2011 Ch'ibal y cuuchcabal: Una consideración sobre su función en la organización política de los mayas yucatecos del posclásico. In El despliegue del poder: Nuevos estudios sobre la organización política maya, edited by Ana Luisa Izquierdo, pp. 207-224. Centro de Estudios Mayas, Instituto de Investigaciones Filológicas, Universidad Nacional Autónoma de México, Mexico City.

Patrois, Julie

2013 Río Bec Graffiti: A Private Form of Art. Ancient Mesoamerica 24: 433-447.

Peebles, Christopher S., and Susan M. Kus

1977 Some Archaeological Correlates of Ranked Societies. American Antiquity 42:421-448.

Pereira, Grégory

2013 Ash, Dirt, and Rock: Burial Practices at Río Bec. Ancient Mesoamerica 24:449-468.

Peterson, Christian E., and Robert D. Drennan

2005 Communities, Settlements, Sites, and Surveys: Regional-Scale Analysis Of Prehistoric Human Interaction. American Antiquity 70:5-30.

Ponce de León, María Josefa Iglesias, Rogelio Valencia Rivera, and Andrés Ciudad Ruiz (editors)

2006 Nuevas ciudades, nuevas patrias: Fundación, refundación y relocalización de las ciudades en Mesoamérica and el Mediterraneo antiguo. Publicaciones de la S.E.E.M. No. 8. Sociedad Española de Estudios Mayas, Madrid.

Pyburn, Anne K.

1998 Smallholders in the Maya Lowlands: Homage to a Garden Variety Ethnographer. Human Ecology 26:267-286.

Reents-Budet, Doris

2001 Classic Maya concepts of the royal court: an analysis of renderings on pictorial. In Royal Courts of the Ancient Maya, Vol. 2: Data and Case Studies, edited by Takeshi Inomata and Stephen D. Houston, pp. 195-233. Westview Press, Boulder, CO.

Restall, Matthew

1997 The Maya World: Yucatec Culture and Society, 1550-1850. Stanford University Press, Stanford.

2001 The People of the Patio: Ethnohistorical Evidence of Yucatec Maya Royal Courts. In Royal Courts of the Ancient Maya, Vol. 2: Data and Case Studies, edited by Takeshi Inomata and Stephen D. Houston pp. 335-390. Westview Press, Boulder, CO.

Rice, Prudence M.

2004 Maya Political Science: Time, Astronomy, and the Cosmos. University of Texas Press, Austin.

Ringle, William M., and George J. Bey III

2001 Postclassic and Terminal Classic Courts of the Northern Maya Lowlands. In Royal Courts of the Ancient Maya, Vol. 2: Data and Case Studies, edited by Takeshi Inomata and Stephen D. Houston pp. 266-307. Westview Press, Boulder, CO

Robin, Cynthia

2003 New Directions in Classic Maya Household Archaeology. Journal of Archaeological Research 11:307-356

Sanders, Donald

1990 Behavioral Conventions and Archaeology: Methods for the Analysis of Ancient Architecture. In Domestic Architecture and the Use of Space: An Interdisciplinary Cross-Cultural Study, edited by Susan Kent, pp. 43-72. Cambridge University Press, Cambridge.

Sanders, William T.

1989 Household, Lineage, and State at Eighth-Century Copan, Honduras. In The House of the Bacabs, Copan, Honduras, edited by David Webster, pp. 89-105. Pre-Columbian Art and Archaeology Studies, No. 29. Dumbarton Oaks, Washington, DC.

1992 Ranking and Stratification in Prehispanic Mesoamerica. In Mesoamerican Elites: An Archaeological Assessment, edited by Diane Z. Chase and Arlen F. Chase, pp. 278-291. University of Oklahoma Press, Norman.

Sanders, William T., Alba Guadalupe Mastache, and Robert H. Cobean (editors)

2003 El Urbanismo en Mesoamérica Urbanism in Mesoamerica. Instituto Nacional de Antropología e Historia and the Pennsylvania State University, Mexico City and University Park.

Schwarz, Kevin R.

2009 Eckixil: Understanding the Classic to Postclassic Survival and Transformation of a Peten Maya Village. Latin American Antiquity 20:413-442. 
Schwartz, Glenn M., and Steven E. Falconer (editors)

1994 Archaeological Views from the Countryside: Village Communities in Early Complex Societies. Smithsonian Institution Press, Washington, DC.

Sharer, Robert J., and Charles W. Golden

2004 Kingship and Polity: Conceptualizing the Maya Body Politic. In Continuities and Changes in Maya Archaeology: Perspectives at the Millenium, edited by Charles W. Golden and Greg Borgstede, pp. 23-50. Routledge, New York.

Smith, Michael E.

1987 Household Possessions and Wealth in Agrarian States: Implications for Archaeology. Journal of Anthropological Archaeology 6:297-335.

Smith, Michael E., and Katharina J. Schreiber

2005 New World States and Empires: Economic and Social Organization. Journal of Archaeological Research 13:189-229.

Stanton, Travis, W., M. Kathryn Brown, and Jonathan B. Pagliaro

2008 Garbage of the Gods? Squatters, Refuse Disposal and Termination Rituals Among the Ancient Maya. Latin American Antiquity 19: 227-248.

Stone, Andrea

1989 Disconnection, Foreign Insigna, and Political Expansion: Teotihuacan and the Warrior Stelae of Piedras Negras. In Mesoamerica and the Decline of Teotihuacan. A.D. 700-900, edited by Richard A. Diehl and Janet C. Berlo, pp. 153-172, Dumbarton Oaks, Washington, DC.

Taladoire, Eric, Sara Dzul, Philippe Nondédéo, and Mélanie Forné

2013 Chronology of the Río Bec Settlement and Architecture. Ancient Mesoamerica 24:353-372.

Terraciano, Kevin

2001 The Mixtecs of Colonial Oaxaca. Stanford University Press, Stanford.

Testart, Alain

2005 Eléments de classification des sociétés. Errance, Paris

Thomas, Prentice M., and L. Janice Campbell

2008 Excavations at Río Bec Group B, Structure 6N-1, Mexico. Estudios de Cultura Maya 31:149-161.

Tourtellot, Gair

1988a Excavations at Seibal, Department of Peten, Guatemala: Peripheral Survey and Excavation, Settlement and Community Patterns. Memoirs of the Peabody Museum Vol. 16. Harvard University Press, Cambridge.

1988b Developmental Cycles of Households and Houses at Seibal. In Household and Community in the Mesoamerican Past, edited by Richard R. Wilk and Wendy Ashmore, pp. 95-120. University of New Mexico Press, Albuquerque.

1993 A View of Ancient Maya Settlements in the Eighth Century. In Lowland Maya Civilization in the Eighth Century A.D., edited by Jeremy A. Sabloff and John S. Henderson, pp. 219-241. Dumbarton Oaks, Washington, DC.
Tourtellot, Gair, Francisco Estrada Belli, John J. Rose, and Norman Hammond

2003 Late Classic Maya Heterarchy, Hierarchy, and Landscape at La Milpa, Belize. In Heterarchy, Political Economy, and the Ancient Maya, edited by Vernon L. Scarborough, Fred Valdez Jr., and Nicolas Dunning, pp. 37-51. University of Arizona Press, Tucson.

Valdés, Juan Antonio

2001 Palaces and Thrones Tied to the Destiny of the Royal Courts in the Maya Lowlands. In Royal Courts of the Ancient Maya, Vol. 2: Data and Case Studies, edited by Takeshi Inomata and Stephen D. Houston, pp. 139-164. Westview Press, Boulder, CO.

Vogt, Evon Z

1983 Ancient and Contemporary Maya Settlement Patterns. In Prehistoric Settlement Patterns: Essays in Honor of Gordon R. Willey, edited by Evon Vogt and Richard Leventhal, pp. 89-114. University of New Mexico Press, Albuquerque.

Watanabe, John M.

2004 Some Models in a Muddle: Lineage and House in Classic Maya Social Organization. Ancient Mesoamerica 15:159-166.

Webster, David

1989 The House of the Bacabs, Copan, Honduras. Precolumbian Art and Archaeology Studies, No. 29. Dumbarton Oaks, Washington DC.

1992 Maya Elites: The Perspective from Copan. In Mesoamerican Elites: An Archaeological Assessment, edited by Diane Z. Chase and Arlen F. Chase, pp. 135-156. University of Oklahoma Press, Norman.

2002 The Fall of the Ancient Maya. Thames and Hudson, New York.

Webster, David, and Elliot Abrams

1983 An Elite Compound at Copan, Honduras. Journal of Field Archaeology 10:285-296.

Webster, David, AnnCorrine Freter, and Nancy Gonlin

2000 Copan: The Rise And Fall of an Ancient Maya Kingdom. Wadsworth/Thomson Learning, Belmont, CA.

Webster, David, and Takeshi Inomata

2004 Identifying Subroyal Elite Palaces at Copan and Aguateca. In Palaces of the Ancient New World, edited by Susan T. Evans and Joanne Pillsbury, pp. 149-180. Dumbarton Oaks, Washington, DC.

Wilk, Richard R.

1988 Maya Household Organization: Evidence and Analogies. In Household and Community in the Mesoamerican Past, edited by Richard R. Wilk and Wendy Ashmore, pp. 135-151. University of New Mexico Press, Albuquerque.

1990 The Built Environment and Consumer Decisions. In Domestic Architecture and the Use of Space: An Interdisciplinary Cross-Cultural Study, edited by Susan Kent, pp. 34-42. Cambridge University Press, Cambridge.

Willey, Gordon R., and Richard M. Leventhal

1979 Prehistoric Settlement at Copan. In Maya Archaeology and Ethnohistory, edited by Norman Hammond, pp. 57-102. University of Texas Press, Austin. 